\title{
Fisheries Regulation in the Maritime Zones of Svalbard
}

\author{
E.J. Molenaar ${ }^{1}$ \\ Senior Research Associate, Netherlands Institute for the Law of the Sea (NILOS), \\ Utrecht University, The Netherlands \\ Adjunct Professor, University of Tromsø, Norway
}

\begin{abstract}
The main focus of this article is the regulation of fishing in the maritime zones of Svalbard in light of both the Spitsbergen Treaty and the international law of the sea. It examines the legal positions of Norway, other states and the European Commission/European Union on, inter alia, the spatial scope of the Spitsbergen Treaty and complements this with analyses of relevant (sub-)regional and bilateral fisheries instruments and Norwegian legislation. These analyses illustrate, inter alia, that the practice of many states and entities involved seeks to reconcile legal positions on the spatial scope of the Spitsbergen Treaty with a raft of other interests. The conclusions also devote attention to possible pathways to resolve diverging positions, as well as to the potential for Norway to address the issue of unregulated fisheries in the context of the rapid pace of climate change in the Arctic.
\end{abstract}

\section{Keywords}

Svalbard; Spitsbergen Treaty; law of the sea; international fisheries law; Arctic; climate change

\section{Introduction}

The Arctic archipelago of Svalbard is located between Greenland and Franz Josef Land - the latter belonging to the Russian Federation-in the far north of the North-East Atlantic Ocean, on the rim of the Arctic Ocean. The

\footnotetext{
1 The article is up to date as of 19 October 2011 (and builds on a report co-authored with A.G. Oude Elferink with the title "The Regulation of Fishing Activities in the Maritime Zones of Spitsbergen”, of 7 June 2011, commissioned by the Netherlands Ministry for Economic Affairs, Agriculture and Innovation). Updating and transforming the report into this article was facilitated by funding from the Netherlands Polar Programme and the Research Council of Norway. The author is very grateful for comments on earlier drafts and assistance received by a large number of persons, including in particular Gerard van Balsfoort, Jan-Pieter Groenhof (and others in the Norwegian government), Tore Henriksen, Alex Oude Elferink, Gunnar Sander and an anonymous reviewer.
} 
archipelago comprises Bear Island (Bjørnøya) and all other islands within a rectangle defined in Article 1 of the Spitsbergen Treaty (see Fig. 1 below). ${ }^{2}$

The use of the name 'Spitsbergen' in the full title of the Spitsbergen Treaty can be traced back to Dutchman Willem Barents's voyage in 1596. This voyage was aimed at finding the fabled North-East Passage to the Far East and led to sightings of, and landings at Bear Island and the main archipelago, part of which was named 'Spitsbergen'. 'Spitsbergen' was from then on the most widely used name for the archipelago and this eventually culminated in its use in the Spitsbergen Treaty. In the 1920s, Norway officially renamed the archipelago 'Svalbard' and the main island 'West Spitsbergen' eventually became 'Spitsbergen'. ${ }^{4}$ Twelfth-century accounts of a land named Svalbaro-which can be translated as 'cold shores'-could mean that the main islands of the archipelago were discovered by Scandinavians as early as then. However, the accounts may also have referred to Jan Mayen or a part of eastern Greenland. ${ }^{5}$ The current article uses the name Svalbard, except in relation to citations.

Hunting for whales, walruses and other marine mammals commenced soon after Barents's 1596 voyage and some of this rapidly became unsustainable. Exploitation of whales had already ended when Russians began hunting for furs at the beginning of the 18th century. While the Russian fur hunt lasted until around 1850, Norwegian fur hunting started in the beginning of the 19th century. Around the end of the 19th century, the focus of attention shifted towards terrestrial mining, in particular for coal. ${ }^{6}$ This is clearly reflected in the prominence given to mining in the Spitsbergen Treaty. ${ }^{7}$

While several states claimed sovereignty over Svalbard at different times in the period between Barents's 1596 voyage and the First World War (WWI), the prevailing view among states as to Svalbard's legal status under international law was that of terra nullius. Once terrestrial mining activity expanded,

\footnotetext{
2 Treaty concerning the Archipelago of Spitsbergen, Paris, 9 February 1920. In force 14 August 1925; 2 League of Nations Treaty Series 7 (1920). The current status of participation in the Spitsbergen Treaty is reproduced in Annex I to this article.

3 Cf. M. Conway, No Man's Land. A History of Spitsbergen from Its Discovery in 1596 to the Beginning of the Scientific Discovery of the Country (Damms Antikvariat: 1906), at pp. 11-15.

4 The name Svalbard already appears in the Act of 17 July 1925, No. 11, 'relating to Svalbard', as amended and the 'Mining Code for Spitsbergen (Svalbard)', laid down in the Royal Decree of 7 August 1925, No. 00, as amended (for information on Norwegian legislation see note 14 infra). Note that the Svalbard Act still refers to West Spitsbergen in its Section 1.

5 Cf. G. Ulfstein, The Svalbard Treaty. From Terra Nullius to Norwegian Sovereignty (Oslo, Scandinavian University Press: 1995), pp. 33-34.

${ }^{6}$ Ibid., pp. 34-38. Limited fur hunting still continues in Svalbard today.

7 See Art. 8, the mining regulations which Norway was to provide pursuant to Art. 8-which eventually led to the 1925 'Mining Code for Spitsbergen (Svalbard)', note 4 supra-as well as issues on land claims governed by Arts. 6-7 and the Annex to the Spitsbergen Treaty.
} 
however, the shortcomings of this status quickly became apparent. Shortly before WWI, international negotiations were held to develop a multilaterally agreed legal status for Svalbard. ${ }^{8}$ Even though they produced two draft treaties, ${ }^{9}$ the negotiations had to be discontinued due to the outbreak of WWI. A new negotiation process was started within the framework of the post-WWI Paris Peace Conference (1919-1920), albeit without the full participation of Germany and Russia, which both had been very active in the earlier negotiations. ${ }^{10}$ The point of departure of the new multilaterally agreed legal status is reflected in the Treaty's Article 1, which recognizes the "full and absolute sovereignty of Norway over the Archipelago of Spitsbergen". ${ }^{11}$

The main focus of this article is the regulation of fishing in the maritime zones of Svalbard in light of both the Spitsbergen Treaty and the international law of the sea, in particular the Law of the Sea (LOS) Convention. ${ }^{12}$ While the considerable body of existing literature on this topic ${ }^{13}$ devotes, inter alia,

\footnotetext{
${ }^{8}$ See the overview in Revue Générale de Droit Internationale Public, vol. XX (1913), pp. 277-282.

9 The second of these drafts was published in Revue Générale de Droit Internationale Public, vol. XX (1913), pp. 282-297. According to Ulfstein 1995, note 5 supra, at pp. 39-41, the main disagreement on this elaborate draft was the composition of the Spitsbergen Commission that would be established pursuant to its Art. 6. Germany and the United States insisted on their participation in this Commission alongside Norway, Russia and Sweden, but Russia in particular disagreed. Ulfstein also describes the substance of a draft treaty prepared in 1919 by a committee established by the Norwegian coal company Store Norske (p. 43). This draft proved to be quite influential in the negotiations within the Spitsbergen Commission, established by the Supreme Council of the Paris Peace Conference.

${ }^{10}$ Cf. Ulfstein 1995, note 5 supra, at p. 46.

${ }_{11}$ See also note 51 infra and accompanying text.

12 United Nations Convention on the Law of the Sea, Montego Bay, 10 December 1982. In force 16 November 1994, 1833 United Nations Treaty Series 396; <www.un.org/Depts/los>.

${ }^{13}$ For literature on this topic see, inter alia, R.R. Churchill and G. Ulfstein, Marine Management in Disputed Areas. The Case of the Barents Sea, (London and New York, Routledge: 1992); T. Pedersen, "The Svalbard Continental Shelf Controversy: Legal Disputes and Political Rivalries", 37 Ocean Development \& International Law 339-358 (2006); C.A. Fleischer, The New International Law of the Sea and Svalbard, paper presented at the 150th Anniversary Symposium of The Norwegian Academy of Science and Letters, on 25 January 2007 (text available at <www.dnva.no/c26889/artikkel/vis.html?tid=27090>); T. Pedersen, Conflict and Order in Svalbard Waters, Ph.D. dissertation for the University of Tromsø, April 2008 (on file with author), D.H. Anderson, "The Status under International Law of the Maritime Areas around Svalbard”, 40 Ocean Development \& International Law 373-384 (2009), T. Pedersen and T. Henriksen, "Svalbard's Maritime Zones: The End of Legal Uncertainty?" 24 International Journal of Marine and Coastal Law 141-161 (2009), R.R. Churchill and G. Ulfstein, "The Disputed Maritime Zones Around Svalbard", in M.H. Nordquist, T.H. Heidar and J.N. Moore (eds.) Changes in the Arctic Environment and the Law of the Sea (Leiden, Martinus Nijhoff Publishers: 2010), pp. 551-593 and R.E. Fife, "Svalbard and the Surrounding Maritime Areas", in High North Study Tour (publication produced in cooperation with the Norwegian Polar Institute, the University Centre in Svalbard, SINTEF, the Norwegian University of
} 
much attention to the diverging legal positions of States, the present article complements this with new developments and specific attention to the position of the European Commission and the European Union (EU). In addition, analyses of relevant (sub-)regional and bilateral fisheries instruments and Norwegian legislation and other implementation action are provided to enhance insight into state practice. In view of the considerable number of relevant Norwegian acts and central regulations and the fact that up-to-date English translations are not available for many ${ }^{14}$ —if not most—of these, this article does not purport to be a robust and comprehensive analysis of relevant Norwegian legislation.

While no account is taken of the conservation and sustainable use of marine mammals, the term 'fish' is otherwise interpreted broadly to include molluscs and crustaceans. The main target fish species in the maritime zones of Svalbard are currently North-East Arctic cod (Gadus morhua), haddock (Melanogrammus aeglefinus), Norwegian spring-spawning (Atlanto-scandian (AS)) herring (Clupea harengus) and shrimp (Pandalus borealis). In view of the highly dynamic nature of marine ecosystems, the constantly evolving impacts of climate change in the Arctic, as well as events like invasions of 'alien' species (e.g., Red King crab (Paralithodes camtschaticus)), however, other fish species could become more prominent in the maritime zones of Svalbard and sustain commercial fisheries. Likewise, the main current target fish species and the commercial fisheries they sustain could become less prominent.

The article is structured as follows. The next section provides an overview of 'Svalbard's Maritime Zones'. This is then followed by the section 'Positions by States and the European Commission/EU on the Spatial Scope of the Spitsbergen Treaty and Fisheries Regulation in Svalbard's Maritime Zones'. The ensuing section, 'Relevant (Sub-)Regional and Bilateral Fisheries Instruments', examines (sub-)regional and bilateral fisheries instruments that are relevant for fisheries regulation in the maritime zones of Svalbard, in particular those that contain provisions that specifically allocate catches to the maritime zones of Svalbard. The next section is on 'Species Regulation, including

\footnotetext{
Science and Technology and the Norwegian Ministry of Foreign Affairs), pp. 18-26 (text also available at <www.regjeringen.no/en/dep/ud/selected-topics/civil--rights/spesiell-folkerett/ folkerettslige-sporsmal-i-tilknytning-ti.html?id=537481 >; (at the time of writing, Fife was Director-General, Legal Affairs Department of the Royal Ministry of Foreign Affairs of Norway).

${ }^{14}$ Consolidated versions of all Norwegian legislation can be found at <www.lovdata.no>. Some English translations of Norwegian acts and central regulations are available at $<$ www.lovdata.no/info/lawdata.html> and <www.fiskeridir.no/english/fisheries/regulations>, but these are not necessarily up to date. The titles of Norwegian legislation for which no official English translation was available were translated by using Google Translate.
} 
through Catch and Access Restrictions and Allocation'. The article ends with a section on 'Conclusions'. Annex I to this article contains a list of the current participation in the Spitsbergen Treaty in alphabetical order.

\section{Svalbard's Maritime Zones}

The maritime zones of Svalbard (see Fig. 1 below) are determined in relation to the baselines defined in the relevant Regulations of $2001 .{ }^{15}$ Internal waters are all waters landward of these baselines. ${ }^{16}$ Seaward thereof are a 12 -nauticalmile (nm) territorial sea, ${ }^{17}$ a contiguous zone of $12 \mathrm{~nm}$ beyond the outer limit of the territorial sea, ${ }^{18}$ a Fisheries Protection Zone (FPZ) with a maximum width of $200 \mathrm{~nm}$ measured from the baselines ${ }^{19}$ and a continental shelf that extends in three areas seaward of the outer limit of the FPZ. These latter so-called 'outer continental shelf areas' were covered by Norway's submission to the Commission on the Limits of the Continental Shelf (CLCS) in November 2006. ${ }^{20}$

In 2006 a maritime boundary was agreed with Greenland ${ }^{21}$ and, more recently, with the Russian Federation, by means of the 2010 Murmansk

15 These were established by means of the Regulations of 1 June 2001, No. 556, relating to the baselines of the territorial sea around Svalbard', last amended in 2003.

16 Sec. 2 of the Act of 27 June 2003, No. 57, 'relating to Norway's territorial waters and contiguous zone' (reproduced in Law of the Sea Bulletin No. 54 (2004), at p. 97; <www.un.org/ Depts/los/LEGISLATIONANDTREATIES $>$ ). Sec. 1 of the Act stipulates that Norway's territorial waters consist of the territorial sea and internal waters.

${ }_{17}$ Cf. Sec. 2 of the Act of 27 June 2003, No. 57, note 16 supra.

${ }^{18}$ Cf. Sec. 4 of the Act of 27 June 2003, No. 57, note 16 supra.

19 The Svalbard FPZ was established by the Regulations of 3 June 1977, No. 6, 'relating to a fisheries protection zone around Svalbard,' last amended in 2001. These Regulations were adopted pursuant to Sec. 5 of the Act of 17 December 1976, No. 91, 'relating to Norway's economic zone', as amended. The English translation of Sec. 5 of the original text of the Act reproduced in <www.un.org/Depts/los/LEGISLATIONANDTREATIES> stipulates: "Prior to the implementation of the Norwegian economic zone, the King may, for areas referred to in paragraph 1, lay down interim provisions for the protection of fish stocks, for the limitation of foreign fishing and for the rational and proper conduct of fishing activities."

${ }^{20}$ On this point see also subsection 'The Positions of Other States' below.

${ }^{21}$ Agreement between the Government of the Kingdom of Norway on the one hand, and the Government of the Kingdom of Denmark together with the Home Rule Government of Greenland on the other hand, concerning the delimitation of the continental shelf and the fisheries zones in the area between Greenland and Svalbard, Copenhagen, 20 February 2006. In force 2 June 2006; English translation registered at the United Nations on 7 July 2006, Registration No. I-42887, published as an Appendix to A.G. Oude Elferink, "Maritime Delimitation Between Denmark/Greenland and Norway", 38 Ocean Development and International Law 375-378 (2007). 


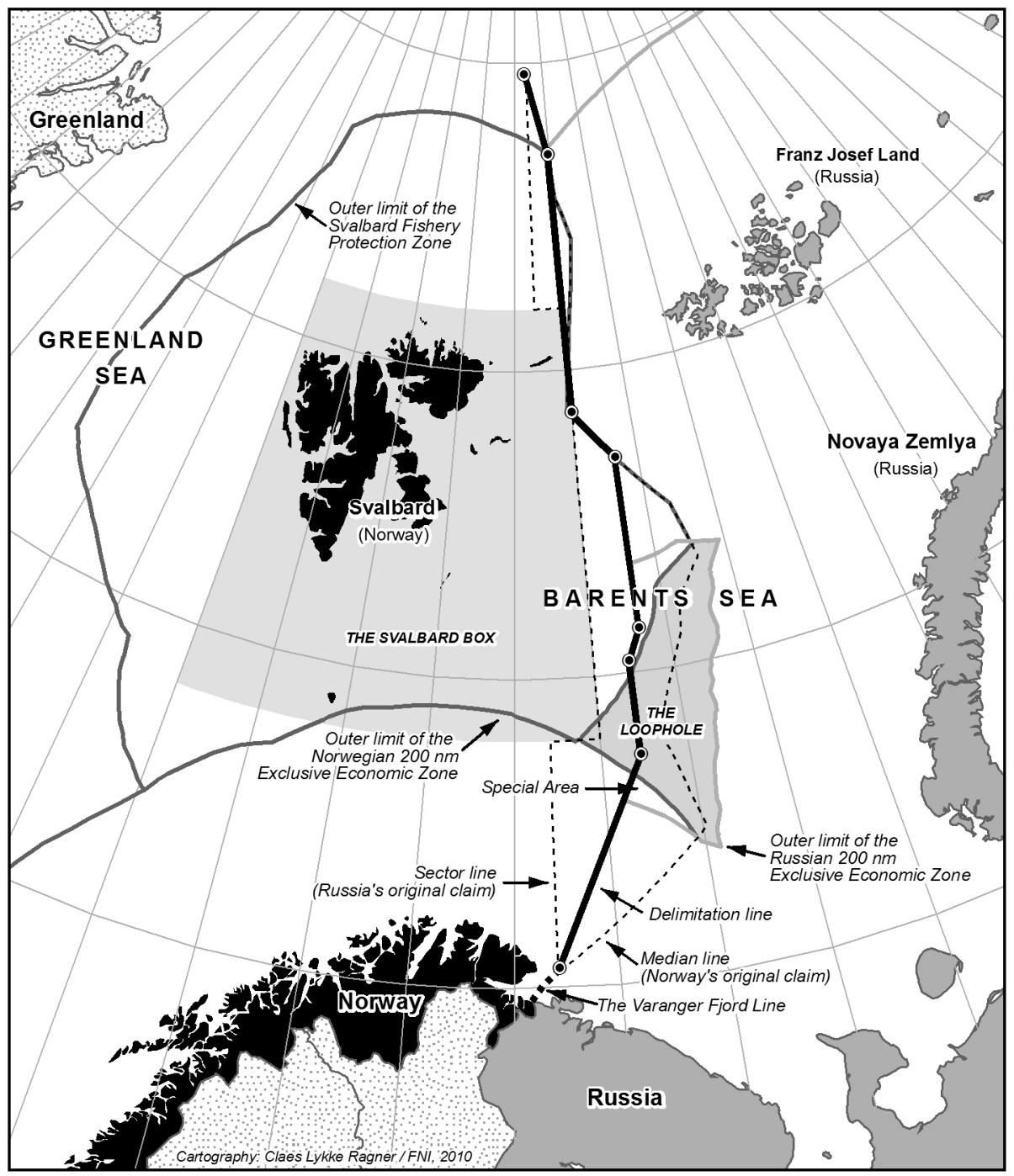

Fig. 1. Maritime boundaries around Svalbard. Map reprinted with permission from Claes Lykke Ragner, the Fridtjof Nansen Institute, who created the map which appeared in the article by $\varnothing$. Jensen, 'The Barents Sea' (2011) 26(1) The International Journal of Marine and Costal Law 151-168, at p. 154.

Treaty. ${ }^{22}$ As regards the latter, its agreed maritime boundary-which comprises both the water column and the continental shelf-creates on the eastern side

22 Treaty between the Kingdom of Norway and the Russian Federation concerning Maritime Delimitation and Cooperation in the Barents Sea and the Arctic Ocean, Murmansk, 15 September 2010. In force 7 July 2011; English text attached to Press Release No. 118/10, of 
two areas which are within $200 \mathrm{~nm}$ from Norwegian baselines but beyond $200 \mathrm{~nm}$ from Russian baselines. Within one of the two areas-namely the one that is within $200 \mathrm{~nm}$ of the Norwegian mainland-the Russian Federation is entitled pursuant to Article 3 of the Murmansk Treaty to the sovereign rights and jurisdiction that would otherwise have belonged to Norway. ${ }^{23}$ These spatially defined Norwegian sovereign rights and jurisdiction are thus transferred to the Russian Federation by means of the Murmansk Treaty. As no such arrangement has been made for the more northerly areawhich lies within $200 \mathrm{~nm}$ of Svalbard's baselines-its waters have become part of the high seas. ${ }^{24}$ The spatial scope of the so-called Loophole (i.e., the high seas pocket in the Barents Sea) is therefore enlarged with this more northerly area. The subsection 'The Positions of Other States' below examines in more detail why this more northerly area has been treated differently from the more southern area.

The outer limit of the Norwegian economic zone (EZ) $)^{25}$ is located at the maximum distance of $200 \mathrm{~nm}$ from the mainland's baselines. ${ }^{26}$ This means that the outer limit of the Norwegian EZ lies within $12 \mathrm{~nm}$ of Bear Island's baselines. ${ }^{27}$ At the same time, Bear Island's baselines are used to determine the $200 \mathrm{~nm}$ outer limit of the FPZ south-west of Svalbard. ${ }^{28}$ The spatial scope of Svalbard's maritime zones and - as a corollary-the spatial scope of the rights of other states therein under the Treaty-if and to the extent they exist-have therefore not been optimized. It must be noted, however, that there is no explicit obligation for Norway to do so and it is also not clear if other parties

15 September 2010, at <www.government.no>; information on entry into force obtained from <www.lovdata.no/traktater $>$.

${ }^{23}$ See in this context also Art. 2 of the Murmansk Treaty.

24 This is confirmed by the Norwegian Ministry of Foreign Affairs doc. Prop. 43 S (20102011) 'Proposisjon til Stortinget (forslag til stortingsvedtak) Samtykke til ratifikasjon av overenskomst av 15. september 2010 mellom Norge og Russland om maritim avgrensning og samarbeid $i$ Barentshavet og Polhavet' (Proposition to the Storting (proposal for Parliamentary decision); Consent for ratification of the Agreement of 15 September 2010 between Norway and Russia on maritime delimitation and cooperation in the Barents Sea and Arctic Ocean), at p. 8 (see the text between "En konsekvens [...] av partenes sonejurisdiksjon").

${ }^{25}$ Instead of 'exclusive economic zone (EEZ)', Norwegian enactments and practice use the 'Economic Zone' (e.g., Act of 1976 No. 91, note 19 supra).

26 This is explicitly stipulated in Sec. 1 of the Regulations of 3 June 1977, No. 6, note 19 supra. Churchill and Ulfstein 2010, note 13 supra, at pp. 560-561, note "One possible argument in favour of such a delimitation is that Norway should not be entitled to a smaller mainland zone as a result of having acquired sovereignty over Svalbard".

27 See also note 104 infra.

${ }^{28}$ See in this regard the observations by the International Court of Justice in the Jan Mayen case (Case concerning Maritime Delimitation in the Area between Greenland and Jan Mayen (Denmark v. Norway), Judgment of 14 June 1993; ICJ Reports 1993, p. 38), at para. 85. 
to the Spitsbergen Treaty have objected to Norway's approach. Norway has also not otherwise explicitly delimited the continental shelf of the mainland of Norway with the continental shelf of Svalbard. ${ }^{29}$

\section{Positions by States and the European Commission/EU on the Spatial Scope of the Spitsbergen Treaty and Fisheries Regulation in Svalbard's Maritime Zones}

\section{Introduction}

As Annex I to this article shows, there are currently 40 parties to the Spitsbergen Treaty. 20 of these are European Union (EU) Member States, which means that seven EU Member States are therefore non-parties to the Spitsbergen Treaty, namely Cyprus, Latvia, Lithuania, Luxembourg, Malta, Slovakia and Slovenia. Denmark's adherence to the Spitsbergen Treaty also extends to the Faroe Islands and Greenland. The EU is not a party and Article 10 of the Spitsbergen Treaty is in fact an obstacle to its becoming one, as one of its paragraphs stipulates:

Third Powers will be invited by the Government of the French Republic to adhere to the present Treaty duly ratified. This adhesion shall be affected by a communication addressed to the French Government, which will undertake to notify the other Contracting Parties.

As entities like the EU did not yet exist in the early 20th century, it can be safely assumed that the term 'Third Powers' was only meant to comprise states. However, nothing in the Treaty would seem to prevent an invitation for accession to be sent to the EU, provided it has the backing of all the contracting parties. ${ }^{30}$

Reference should also be made to other important non-parties in this context. Among these is South Korea, which in recent years has expressed considerable interest in the Arctic, underscored by its attendance at recent Arctic Council Senior Arctic Officials (SAOs) meetings and the 2009 and 2011 Ministerial Meetings. It is interesting that the Spitsbergen Treaty and

\footnotetext{
29 See the comments by Anderson, note 13 supra, at pp. 377-378, and those by Churchill and Ulfstein 2010, note 13 supra, at p. 561. Pedersen 2006, note 13 supra, at p. 344 describes the Norwegian view as postulated by C.A. Fleischer.

${ }^{30}$ Attention would nevertheless have to be devoted to avoiding problems on decision-making, even though the Spitsbergen Treaty does not have a permanent institutional component (but see Art. 8).
} 
South Korea's accession may currently be under review by the South Korean Government. ${ }^{31}$ Several states that currently hold the status of cooperating non-contracting parties (CNPs) granted by the North-East Atlantic Fisheries Commission (NEAFC) ${ }^{32}$ (viz. Belize and Cook Islands), or that applied for it in the recent past (viz. Bahamas and Panama), are all non-parties to the Spitsbergen Treaty as well. ${ }^{33}$

As the Preamble to the Spitsbergen Treaty notes, the recognition of Norwegian territorial sovereignty is balanced by the desire to provide the territories with "an equitable regime, in order to assure their development and peaceful utilization". Article 1 accordingly makes recognition of Norwegian territorial sovereignty "subject to the stipulations of the present Treaty". In addition to the desire for an equitable regime expressed in the Preamble, the most important stipulations - for the purposes of this article - are the rights of equal access and treatment in relation to fishing and hunting in Article 2 and the "equal liberty of access and entry for any reason or object whatever to the waters, fords and ports" under Article 3.

It is submitted that, as the sovereign of Svalbard, Norway's territorial jurisdiction can be assumed to be unrestricted, provided it conforms to the stipulations of the Treaty. ${ }^{34}$ Article 2 of the Treaty nevertheless confirms that:

Norway shall be free to maintain, take or decree suitable measures to ensure the preservation and, if necessary, the re-constitution of the fauna and flora of the said regions, and their territorial waters; it being clearly understood that these measures shall always be applicable equally to the nationals of all the High Contracting Parties without any exemption, privilege or favour whatsoever, direct or indirect to the advantage of any one of them.

${ }^{31}$ Information provided to the author by email on 15 June 2010 by an official of the South Korean Ministry of Foreign Affairs and Trade.

32 Established by the NEAFC Convention (Convention on Future Multilateral Cooperation in the North-East Atlantic Fisheries, London, 18 November 1980. In force 17 March 1982, 1285 United Nations Treaty Series 129; <www.neafc.org>. 2004 Amendments (Art. 18bis), London; 12 November 2004. Not in force, but provisionally applied by means of the 'London Declaration' of 18 November 2005; <www.neafc.org>. 2006 Amendments, London (Preamble, Arts. 1, 2 and 4), 11 August 2006. Not in force, but provisionally applied by means of the 'London Declaration' of 18 November 2005; <www.neafc.org>. At the 2009 Annual Meeting of NEAFC, only the EU and Norway were able to report that they had concluded the ratification process (cf. Report of the 2009 NEAFC Meeting, at p. 24). The Report of the 2010 NEAFC Meeting does not provide new information on the issue).

33 Based on information on NEAFC websites <www.neaf.org> and <archive.neafc.org>, accessed 13 September 2011. The information on the Bahamas and Panama is based on the 2009 Report of NEAFC.

${ }^{34}$ Norway's position on this is different (see subsection 'The Position of Norway'). 
The reference in Article 2 to territorial waters-which comprise both internal waters and the territorial sea-implies that the spatial scope of the Treaty also extends to the territorial sea. As the Treaty was adopted in 1920, however, it is no surprise that no mention was made of the continental shelf or the EEZ, because these maritime zones simply did not exist at the time. But once these maritime zones became part of the general practice of states, the question arose as to how the situation of Svalbard should be dealt with.

Even though the second draft produced in the pre-WWI negotiation ${ }^{35}$ contained a dispute settlement mechanism and a permanent institutional component, the Spitsbergen Treaty contains neither. As regards the latter aspect, however, reference must be made to Articles 4, 5 and 8. Article 4(1) provides that equal access to public wireless telegraphy stations "established or to be established by or with the authorisation of" the Norwegian government must be consistent with the 1912 "Wireless Telegraphy Convention" or its successor; which at present are the Constitution of the International Telecommunication Union (ITU) and the Convention of the International Telecommunication Union. ${ }^{36}$ Implicitly, therefore, Norwegian regulation of access must be consistent with these instruments and, presumably, with any Administrative Regulations in force subsequently adopted under the aegis of the ITU.

As regards Article 5 of the Spitsbergen Treaty, its paragraph (1) relates to an "international meteorological station [...] the organisation of which shall form the subject of a subsequent Convention", neither of which has so far materialized. Paragraph (2) stipulates that "Conventions shall also be concluded laying down the conditions under which scientific investigations may be conducted in the said territories". While paragraph (1) does not explicitly or implicitly impinge on Norwegian jurisdiction, paragraph (2) raises the question whether or not Norway has, in the absence of multilaterally agreed regulations on scientific research, the right to do this unilaterally. This question should take due notice of the fact that the Spitsbergen Treaty lacks an explicit right for (the nationals of ) states parties to engage in scientific research. Ulfstein argues that the travaux préparatoires demonstrate that such a right was deliberately omitted. ${ }^{37}$ In light of the possibility of the formation of rules of customary international law, however, it is relevant to note that significant extensive scientific research activities have been undertaken during extended

\footnotetext{
35 See note 9 supra.

36 Both adopted in Geneva in 1992, and frequently amended since then. Consolidated versions of the Constitution and the Convention are available at <www.itu.int $>$.

37 Ulfstein 1995, note 5 supra, at p. 395.
} 
periods of time by both parties and non-parties (e.g., South Korea) and that Norway has so far not regulated scientific research as such. ${ }^{38}$

Article 8 of the Spitsbergen Treaty stipulates that Norway "undertakes to provide" mining regulations. ${ }^{39}$ In case the other High Contracting Parties would have proposed modifications to the draft mining regulations provided by Norway, such proposals would have had to be examined and subjected to majority decision-making by a Commission composed of representatives of the contracting parties. ${ }^{40}$

As Articles 4, 5 and 8 of the Spitsbergen Treaty should be regarded as an exhaustive list of topics for which a multilateral component exists, there is no convincing basis for arguing that a multilateral component in relation to the conservation and management of marine living resources is either required by, or consistent with, the Treaty.

\section{The Position of Norway}

According to Norway, the point of departure for the interpretation of the Spitsbergen Treaty is that restrictions on Norway's sovereignty should not be assumed. As formulated in the 1999 Svalbard Report to the Storting:

It is an accepted principle of international law relating to treaty interpretation that any significant restriction of sovereignty over land territory must be clearly based on a treaty. Such provisions are to be interpreted on the basis of their natural linguistic meaning. In cases of doubt, the interpretation that entails the least restriction of the exercise of authority is to be adopted. Article 1 of the Treaty grants Norway the full and absolute sovereignty over the archipelago, and the Treaty does not provide for any general restriction of Norway's sovereignty. Therefore, unless otherwise specifically provided in the Treaty, Norway has complete jurisdiction in accordance with the general rules of public international law. ${ }^{41}$

\footnotetext{
38 Scientific research activities are nevertheless subject to the Act of 15 June 2001, No. 79, 'relating to environmental protection in Svalbard (Svalbard Environment Act)', as amended, and certain procedural requirements (e.g., the obligation to register in the Research in Svalbard (RiS) data base (see <www.ssf.npolar.no/pages/database.htm>)).

39 These eventually became the 1925 'Mining Code for Spitsbergen (Svalbard)', note 4 supra.

40 See also Churchill and Ulfstein 1992, note 13 supra, at pp. 31-32.

411999 Svalbard Report to the Storting (Report No. 9 to the Storting (1999-2000), 'Svalbard', Recommendation of 29 October 1999 by the Ministry of Justice and the Police, approved in the Council of State on the same date (available at <www.regjeringen.no/nb/dep/ $\mathrm{jd} /$ dok/regpubl/stmeld $>$, accessed on 10 June 2011), section 4.1.1.
} 
If correct, this has obviously far-reaching consequences. It must be noted, however, that there is considerable opposition to the Norwegian position. ${ }^{42}$ An in-depth analysis of the relevant international case-law-as is provided by some of the commentators cited-is beyond the scope of this article.

As regards the spatial scope of application of the Treaty, Norway takes the position that it ends at the outer limit of the territorial sea. The normal law of the sea regime applies seaward thereof, thus entitling Norway to a continental shelf and EEZ and their associated sovereign rights and jurisdiction. ${ }^{43}$ This is supported by the following reasoning, described by Fife:

The regime of the economic zone and other 200-mile zones does not, according to established international law, result from a conversion of prior territorial waters. Instead, it represents a special legal regime that replaced a prior regime of the high seas, under which international cooperation on resource management has not led to satisfactory results, prompting the establishment of coastal State zones. Moreover, in accordance with established international law, the notion of the continental shelf cannot be assimilated to the concept of territory of a State. ${ }^{44}$

Norway also seems to invoke the obligations it has as a party to the LOS Convention - in its capacity as a coastal state-with respect to the conservation and management of marine living resources in the EEZ. ${ }^{45}$ It is submitted, however, that such obligations only become applicable once a coastal state has chosen to make use of its sovereign rights in a $200-\mathrm{nm}$ zone by means of establishing it. Arguments to the effect that these obligations support these sovereign rights per se, or that exercising sovereign rights is mandatory instead of optional, are not in line with the LOS Convention and are also not relevant for the interpretation of the Spitsbergen Treaty.

Despite claiming a right to establish a regular EEZ and to exercise therein the associated sovereign rights in the usual fashion, Norway has so far chosen not to make use thereof. Instead, Norway established an FPZ in 1977, mainly

\footnotetext{
42 See, inter alia, Anderson, note 13 supra, at pp. 379-380, and Churchill and Ulfstein 2010, note 13 supra, at pp. 566-584.

${ }^{43}$ Cf. Churchill and Ulfstein 1992, note 13 supra, at p. 40, referring to Stortingsmelding 40, 1985-6, p. 9; and Fife, note 13 supra, at p. 22.

${ }_{44}$ Fife, note 13 supra, at p. 22. This text appears almost verbatim also in a Letter of 9 August 2011 from the Royal Ministry of Foreign Affairs of Norway to the EU Delegation to Norway (on file with author), which responds to the Note Verbale No. 19/11, of 8 July 2011, from the EU Delegation to Norway to the Royal Ministry of Foreign Affairs of Norway (on file with author).

45 See, for instance, Fife, note 43 supra, at pp. 23 and 24, and Pedersen and Henriksen, note 13 supra, at pp. 160-161 who, inter alia, refer to Art. 61 of the LOS Convention.
} 
for the purpose of the conservation and management of marine living resources. According to Fife:

The rules governing the zone are formulated in such a way that they would not be in conflict with those of the 1920 Treaty even if the latter's provisions had applied to the Fisheries Protection Zone. The regulatory measures for fisheries are based on objective protection and management needs and take into account previous foreign fishing patterns in the area. ${ }^{46}$

As a corollary to the above positions, Norway takes the position that it has the usual coastal state competence to regulate fishing activities by means of prescribing conservation and management measures and of ensuring compliance through enforcement, including at-sea boarding, inspection and arrest of foreign vessels. This competence relates to the territorial waters, as well as the FPZ, of Svalbard. As regards prescriptive jurisdiction, the above positions imply the absence of a duty for Norway to consult with other parties. ${ }^{47}$ The lack of a multilateral component on fisheries in the Spitsbergen Treaty could be regarded as supporting the Norwegian position. ${ }^{48}$

From Norway's general position on the interpretation of the Spitsbergen Treaty it also follows that Norway has full enforcement jurisdiction in the territorial waters of Svalbard. Norway could presumably raise the subsidiary argument that the words "maintain, take or decree" and "applicable" in Article 2 of the Spitsbergen Treaty, as well as the words "subject to the observance of local laws and regulations" in its Article 3, also support full Norwegian enforcement jurisdiction. Churchill and Ulfstein submit that Norwegian enforcement jurisdiction in the territorial waters of Svalbard appears to be uncontested by the other parties. ${ }^{49}$ For parties that indeed do not contest this and which share the position that the Spitsbergen Treaty applies also seaward of the territorial sea, it must follow that full Norwegian enforcement jurisdiction in the FPZ cannot be contested either. ${ }^{50}$

\footnotetext{
46 Fife, note 13 supra, at p. 23.

47 Churchill and Ulfstein 2010, note 13 supra, at p. 555 take the view that "Norway therefore has no more duty to consult with other states on the government of Svalbard than any other state has about the management of its territory".

${ }^{48}$ See note 35 supra and accompanying text.

${ }^{49}$ Churchill and Ulfstein 2010, note 13 supra, at p. 585. However, the EU position on enforcement set out in Note Verbale No 32/09, note 79 infra (discussed in subsection 'The Position of the European Commission/EU') seems to apply also to the territorial waters of Svalbard.

${ }^{50}$ On this point see also Pedersen and Henriksen, note 13 supra, at p. 160.
} 
As regards non-parties to the Spitsbergen Treaty, Norway takes the position that Norwegian sovereignty over Svalbard is also binding and opposable as a consequence of Norwegian effective occupation and exercise of sovereignty and the lack of protest from any state. Moreover, non-parties and their nationals are not entitled to the rights accorded by the Treaty to parties and their nationals. ${ }^{51}$ This position relates of course only to the (land territory and) territorial waters of Svalbard. As Norway takes the position that the Spitsbergen Treaty does not apply seaward thereof, participation in the Treaty is in Norway's view not relevant for the issue of access to resources in the FPZ and of the continental shelf. Presumably, Norway would argue that Articles 62 and 77(2) of the LOS Convention-which are undoubtedly also part of customary international law-entitle it to give access to other states and their nationals, whether or not in return for financial compensation or otherwise.

Reference should nevertheless be made to Norwegian practice with regard to Lithuania prior to Lithuania's EU Membership on 1 May 2004. Lithuania has never been a party to the Spitsbergen Treaty, but a number of its vessels was apparently authorized to fish for shrimp in the territorial waters of Svalbard pursuant to Regulations of 1996 specifically drafted for this purpose. ${ }^{52}$ As a consequence of Lithuania's EU Membership from 1 May 2004 onwards, these Regulations were repealed. ${ }^{53}$ Moreover, the 1997 Regulations on registration of vessels fishing for shrimp were amended for the same reason. ${ }^{54}$ This suggests that vessels flying the flag of Lithuania-a non-party to the Spitsbergen Treaty-were specifically authorized to fish for shrimp in the FPZ prior to 1 May 2004. Furthermore, the current regulations relevant to fishing by vessels of EU Member States in the territorial waters and the FPZ do not specify that only vessels flying the flag of states parties to the Spitsbergen Treaty are entitled to fish. ${ }^{55}$ While this is fully in line with Norway's position on the FPZ of Svalbard, the situation with respect to

\footnotetext{
511999 Svalbard Report to the Storting, note 41 supra, section 4.1.1.

52 Their English title is 'Regulations of 19 July 1996 relating to fishing for shrimps using vessels from Lithuania in the territorial and internal waters of Svalbard'.

53 The 1996 Regulations, note 52 supra, were repealed pursuant to Art. II of the 'Regulations of 31 August 2005 amending the Regulations of 19 July 1996, No. 733, relating to fishing for shrimps using vessels from member states of the European Communities in the territorial and internal waters of Svalbard' (published on 15 December 2005).

54 This concerns amendments (published on 24 March 2006) of the Regulations of 11 July 1997, No. 784, 'relating to registration of vessels that are to take part in shrimp fisheries in the Fisheries Protection Zone around Svalbard and the territorial and internal waters of Svalbard'. 55 This concerns the Regulations of 19 July 1996, No. 733, mentioned in note 53 supra, and the Regulations of 11 July 1997, No. 784, mentioned in note 54 supra.
} 
Norway's position on the territorial waters of Svalbard is different. Presumably, however, Norway might argue that even though Lithuania does not have entitlements pursuant to the Spitsbergen Treaty, such entitlements can be granted pursuant to Norwegian sovereignty over Svalbard, including its territorial waters. Norway might pursue a similar argument with respect to inhabitants of Longyearbyen with nationalities of non-parties to the Spitsbergen Treaty, for instance those with Thai nationality. ${ }^{56}$

\section{The Positions of Other States}

It is significant that there do not seem to be any other states that currently support the Norwegian position on the spatial application of the Spitsbergen Treaty as set out in the previous subsection. ${ }^{57}$ While some states-for instance the United States-have reserved their rights on the issue, ${ }^{58}$ the position of several other states is similar to that of the United Kingdom, which restated its position on the spatial scope of application of the Spitsbergen Treaty as follows in 2006:

[...] The United Kingdom considers that the Svalbard archipelago, including Bear Island, generates its own maritime zones, separate from those generated by other Norwegian territory, in accordance with the United Nations Convention on the Law of the Sea. It follows therefore that there is a continental shelf and an exclusive economic zone which pertain to Svalbard.

Second, the United Kingdom considers that maritime zones generated by Svalbard are subject to the provisions of the Treaty of Paris, in particular Article 7, which requires that Svalbard should be open on a footing of equality to all parties to the Treaty and Article 8, which inter alia specifies the tax regime which applies to the exploitation of minerals in Svalbard.

The United Kingdom expects that the Norwegian authorities will fully comply with the obligations of Norway under the Treaty of Paris, as set out above. ${ }^{59}$

\footnotetext{
${ }^{56}$ For an interesting account see <www.atimes.com/atimes/Southeast_Asia/IC27Ae01.html>, accessed on 7 June 201.

57 Pedersen and Henriksen, note 13 supra, at p. 145 observe that in 2005 Finland withdrew the support it originally expressed in 1976. Canada's support for the Norwegian view was laid down in the Preamble to the Agreement between the Government of the Kingdom of Norway and the Government of Canada on Fisheries Conservation and Enforcement, 30 June 1995 (Proposition No. 3 (1995-96) to the Odelsting)), but the agreement never entered into force. 58 Pedersen and Henriksen, note 13 supra, at p. 145. See also T. Pedersen, "International Law and Politics in U.S. Policymaking: The United States and the Svalbard Dispute", 42 Ocean Development and International Law 120-135 (2011).

59 Note Verbale, of 11 March 2006, by the British Government to the Government of Norway as incorporated in 78 British Yearbook of International Law (2007) 794.
} 
The positions of Denmark (and the Faroe Islands), ${ }^{60}$ Iceland $^{61}$ and the Netherlands ${ }^{62}$ - but presumably now also the Russian Federation and Spain (see below) and other states - are essentially similar, namely that Norwegian sovereignty over Svalbard entitles Norway to establish seaward of the territorial sea the usual maritime zones recognized by the international law of the sea and to exercise therein the associated sovereign rights, jurisdiction (and incidental other rights). However, as the Spitsbergen Treaty applies to these maritime zones, this imposes restrictions on Norwegian sovereign rights and jurisdiction. It has been reported in the literature that the United Kingdom invited nine states — not including Norway-for a meeting in 2006 to discuss legal issues relating to the Spitsbergen Treaty. ${ }^{63}$ This meeting may have led several of these states to align their positions on the Spitsbergen Treaty closer to that of the United Kingdom. ${ }^{64}$

Not all these states are likely to have more specific positions on Norway's legislative and enforcement jurisdiction over fishing activities in the maritime zones of Svalbard, for instance similar to the positions that the European Commission/EU has or used to have (see next subsection). As regards enforcement jurisdiction, Pedersen concludes that the position of Iceland, the Russian Federation and Spain seems similar to the position that the European Commission/EU had and may still have. ${ }^{65}$

Iceland, the Soviet Union/Russian Federation and Spain have at several instances in the past taken the position that Norwegian sovereignty over Svalbard does not entitle Norway to establish — seaward of the territorial seathe usual maritime zones recognized by the international law of the sea and to exercise therein the associated sovereign rights and jurisdiction. Consequently, the outer limit of the territorial sea would constitute the inner limit of not only the high seas but also the 'Area'. ${ }^{66,67}$ This position of the Soviet Union/

${ }^{60}$ See in this regard T. Pedersen, "Denmark's Policies Toward the Svalbard Area", 40 Ocean Development \& International Law 319-332 (2009). As regards the Faroe Islands, see also the subsection 'Norway-Faroe Islands Instruments'.

${ }^{61}$ Cf. a one-pager entitled "The Svalbard Issue”, drafted by T.H. Heidar, Legal Adviser, Ministry of Foreign Affairs of Iceland, June 2010 (on file with author).

${ }^{62}$ Cf. Pedersen 2008, note 13 supra, at p. 22, and T. Pedersen, "The Dynamics of Svalbard Diplomacy", 19 Diplomacy and Statecraft 236-262 (2008), at p. 241, n. 42, based on his analysis of a Netherlands diplomatic note No. 2238, handed to Norway on 3 August 1977.

${ }^{63}$ Cf. Pedersen 2009, note 60 supra, at p. 329. The nine were Canada, Denmark, Finland, France, Germany, Iceland, the Russian Federation, Spain and the United States.

${ }^{64}$ Ibid.

${ }_{65}$ Pedersen 2008, note 13 supra, at pp. 250-251.

66 See Art. 1(1)(1) of the LOS Convention.

${ }^{67}$ Cf. Pedersen and Henriksen, note 13 supra, at pp. 146-148. As regards the view of the Soviet Union/Russian Federation, this can be deduced from the various Notes Verbales 
Russian Federation may well have been influenced by the fact that Russia was an active participant in the pre-WWI negotiations on the legal status of Svalbard and a prospective member of the envisaged Spitsbergen Commission, but could not participate in the Paris Peace Conference that produced the Spitsbergen Treaty. ${ }^{68}$

It is submitted, however, that Iceland, the Russian Federation and Spain at present do not pursue this position any longer. ${ }^{69}$ As regards the Russian Federation and Spain, this can be concluded on the basis of their responses to the Norwegian submission to the CLCS in relation to the North-East Atlantic and the Arctic on 27 November 2006. ${ }^{70}$ Svalbard is relevant for the determination of the outer limit of the continental shelf beyond $200 \mathrm{~nm}$ for all three areas included in this submission. For all three areas, the shelf is (also) adjacent to the FPZ of Svalbard; two areas are certainly in their entirety (also) a natural prolongation of the mainland Norway and one area is certainly in its entirety (also) a natural prolongation of Jan Mayen. The Norwegian submission did not refer to the Spitsbergen Treaty. Conversely, both the Russian Federation and Spain explicitly referred to the Spitsbergen Treaty in Notes Verbales issued in response to the Norwegian submission. ${ }^{71}$ The Russian Federation reserves by means of its Note Verbale its position "towards the Spitsbergen archipelago and its continental shelf" and takes the view that the recommendations of the CLCS shall be without prejudice to the provisions of the Spitsbergen Treaty "and, accordingly, to the regime of the maritime areas adjacent to Spitsbergen". The Spanish Note Verbale emphasizes, inter alia, that the Treaty's provisions on equal access and non-discrimination are also applicable to the continental shelf both within and beyond $200 \mathrm{~nm}$. Subsequently, Norway indicated by means of a Note Verbale issued in response to the Spanish Note Verbale that the issues raised by Spain did "not affect in any manner the

reproduced in the Annexes incorporated in A.N. Vylegzhanin and V.K. Zylanov, Legal Regime of Maritime Spaces Adjacent to Spitsbergen (Iceland: 2006).

68 See note 8 supra and accompanying text. See also Vylegzhanin and Zylanov, note 67 supra, at pp. 19-32, even though their arguments are certainly not always equally convincing.

${ }_{69}$ As regards Iceland, see the non-paper dated 30 March 2006 by the Ministry of Foreign Affairs of Iceland on the status of maritime areas around Svalbard, incorporated in Annex 16 to Vylegzhanin and Zylanov, note 67 supra.

70 'Continental Shelf Submission of Norway in respect of areas in the Arctic Ocean, the Barents Sea and the Norwegian Sea. Executive Summary' (available at <www.un.org/Depts/los $>$ ).

${ }^{71}$ Note Verbale, of 21 February 2007, of the Permanent Mission of the Russian Federation to the United Nations to the Secretary-General of the United Nations; Note Verbale, of 3 March 2007, of the Permanent Mission of Spain to the United Nations to the Secretary-General of the United Nations (both available at <www.un.org/Depts/los $>$ ). 
interpretation or application of the rules contained in article 76 of the [LOS] Convention nor its Annex II". ${ }^{72}$

As neither the Russian Federation nor Spain or other states commented on the ability of Svalbard to generate maritime zones seaward of the territorial sea, even though this would probably have been the most opportune moment to do so, it can be concluded that this ability is currently generally accepted within the international community. Likewise, there has not been any objection against the right of Norway to perform procedural acts in relation to such maritime zones, for instance initiating the procedure with the CLCS. ${ }^{73}$ As regards the designation of maritime zones around Svalbard and the establishment of their outer limits, Norway's competence therefore does not seem to be any different from that of coastal states in general.

With respect to the Russian Federation, this position was recently confirmed by the 2010 Murmansk Treaty. As the agreed boundary incorporated therein does not leave a high seas/Area pocket adjacent to the territorial sea of Svalbard, this reflects Russian recognition that Svalbard generates maritime zones seaward of the territorial sea. As noted in the section 'Svalbard's Maritime Zones' above, east of the agreed boundary are two areas which are within $200 \mathrm{~nm}$ from Norwegian baselines but beyond $200 \mathrm{~nm}$ from Russian baselines. Article 3 of the Murmansk Treaty contains an arrangement for the transfer to Russian Federation of sovereign rights and jurisdiction that would otherwise have belonged to Norway. However, this arrangement only applies to the southerly area.

As the southerly area is within $200 \mathrm{~nm}$ of the Norwegian mainland and the northerly area within $200 \mathrm{~nm}$ from Svalbard, it is reasonable to assume that the absence of a similar arrangement for the more northerly area is directly linked to the Spitsbergen Treaty and the diverging views of Norway and the Russian Federation on the Treaty's spatial scope. States do not seem to contest that sovereignty over Svalbard entitles Norway to negotiate and adopt bilateral maritime boundary agreements with respect to Svalbard. Other contracting parties to the Spitsbergen Treaty may nevertheless take the view that, consistent with their position on the spatial scope of the Spitsbergen Treaty, Norway is in a sense also negotiating on their behalf; namely to safeguard their rights under the Treaty.

72 Note Verbale, of 28 March 2007, of the Permanent Mission of Norway to the United Nations to the Secretary-General of the United Nations (available at <www.un.org/Depts/ los $>$ ).

${ }^{73}$ Cf. Pedersen and Henriksen, note 13 supra, at p. 158. 
A bilateral agreement on land boundaries and/or maritime boundaries is fundamentally different from a bilateral transfer of land, maritime territory and/or other maritime areas. As regards the latter, there was no prior dispute on title or entitlement to certain land, maritime territory or sovereign rights and jurisdiction. Conversely, bilateral boundary agreements are specifically aimed at resolving such disputes. In view of the fact that the international law on delimitation is generally unable to prescribe a single solution or outcome for resolving a specific dispute, agreed boundaries can be viewed as agreed determinations of the largely non-specific international law in specific scenarios.

A key question is whether or not it would be consistent with the Spitsbergen Treaty for Norway to transfer all or part of Svalbard's land, maritime territory and other maritime areas to another state. None of the provisions of the Spitsbergen Treaty address this scenario explicitly or implicitly and it is also unlikely to have been contemplated during the negotiations. As a minimum, other contracting parties would probably insist on arrangements to ensure that the entire regime of the Treaty would become applicable mutatis mutandis to the transferred area. The scenario at hand, however, does not concern land or maritime territory but an area beyond the territorial sea but within $200 \mathrm{~nm}$ of the baselines. Norway takes the position that the Spitsbergen Treaty does not apply to such an area, but the Russian Federation and many other contracting parties to the Spitsbergen Treaty take the view that it does. In light of this disagreement, it must have been impossible for Norway and the Russian Federation to agree on wording for an arrangement along the lines of Article 3 of the Murmansk Treaty that was not only mutually acceptable but also likely to have avoided objections by other contracting parties to the Spitsbergen Treaty.

\section{The Position of the European Commission/EU}

At the outset, it should be re-emphasized that the EU is not a party to the Spitsbergen Treaty and that seven of the current 27 EU Member States are not either. Moreover, according to Article 351 of the Treaty on the Functioning of the European Union (TFEU): ${ }^{74}$

The rights and obligations arising from agreements concluded before 1 January 1958 or, for acceding States, before the date of their accession, between one or

${ }^{74}$ Treaty on the Functioning of the European Union, consolidated version. The Lisbon Treaty amended the Treaty on the European Community, including by changing its name. 
more Member States on the one hand, and one or more third countries on the other, shall not be affected by the provisions of this Treaty.

The position and role of the European Commission and the EU with regard to the Spitsbergen Treaty depend furthermore on the distribution of competence between the EU and its Member States, which in its turn is first of all determined by the TFEU, the EU Treaty ${ }^{75}$ and other treaties concluded within the framework of the EU. The scope and extent of EU competence is governed by the principle of 'conferral of competence' and the use of 'conferred competence' is, inter alia, governed by the principles of subsidiarity and proportionality. ${ }^{76}$ Furthermore, the judgments of the European Court of Justice play a key role in the highly dynamic matter of the distribution of competence. While adjustments of competence can be a consequence of the increasing importance of EU legislation and acts by the European Commission, it can also be negotiated between EU Member States. The latter adjustments can lead to more competence being conferred to the EU but also to competence being delegated back to EU Member States.

Of the five areas listed in Article 3 TFEU in which the EU has exclusive competence, the "conservation of marine biological resources under the common fisheries policy" under (d) is of obvious importance to this article. The consequential external competence of the EU in the sphere of fisheries implies that the EU represents EU Member States, for instance in negotiations with non-EU Member States and in regional fisheries management organizations (RFMOs). Subject to some exceptions, EU Member States cannot become members of RFMOs alongside the EU. One of these exceptions relates to 'overseas countries and territories' and enables, for instance, Denmark to become a member of RFMOs alongside the EU on behalf of the Faroe Islands, Greenland, or both. ${ }^{77}$

The substantive scope of the Spitsbergen Treaty clearly goes far beyond marine capture fisheries. In fact, as the Spitsbergen Treaty confers sovereignty over Svalbard on Norway, it intends to apply to the full range of substantive categories and areas of state sovereignty. Whereas the EU and its Member States share competence in some of these areas, in particular those listed in Article 4(2) TFEU (e.g., environment and transport), there may not be any explicit competence for the EU in other areas.

The European Commission has regularly issued Notes Verbales to Norway since the establishment of the FPZ of Svalbard in 1977, commonly in response

75 Treaty on European Union, consolidated version.

76 See Art. 2(1) and (2) TFEU and Arts. 4 and 5 of the EU Treaty.

77 For instance in the context of the NEAFC Convention, see note 32 above. 
to incidents involving fishing vessels flying the flag of EU Member States. Three of these are examined in more detail below, namely Notes Verbales No. $26 / 04,{ }^{78}$ No. $32 / 09^{79}$ and No. $19 / 11{ }^{80}$ Notes Verbales No. $26 / 04$ and No. 32/09 were issued on 20 July 2004 and 4 September 2009, respectively, in the aftermath of Norwegian enforcement measures against the Spanish fishing vessels Olazar and Olaberri on 31 May 2004 and against the Portuguese vessel Praia de Santa Cruz on 19/20 August 2009, respectively. Note Verbale No. 32/09 is virtually identical to Note Verbale No. 26/04 and contains the following text:

The European Community's consistent position on the status of the archipelago of Svalbard under the Treaty of Paris of 1920, the applicability of the relevant provisions of the Treaty to fishing activities within the Fisheries Protection Zone around Svalbard and the conditions and limits placed upon Norway's entitlement to take measures for the conservation of the fisheries resources in these waters under the Treaty, has been expressed many times. In view of this most recent incident, where a Portuguese vessel was arrested by the Norwegian authorities and diverted to the Norwegian port of Troms $[\varnothing]$ and charges are being proffered under the Norwegian legal system, the European Community wishes to repeat its positions, namely, that the specific provisions of the Treaty of Paris, and in particular those of Article 2 on its rights with respect to the exercise of fishing activities under the Treaty of Paris, apply in this case.

In respect of the incident of 19/20 August 2009, the European Community wishes to express surprise and concern that Norway has taken enforcement action against a vessel of one of the High Contracting Parties to the Treaty of Paris engaged in fishing activity in the waters around Svalbard. The European Community demands that Norway cease and desist from any further similar action against vessels entitled to fly the flag of a Member State of the European Community. The European Community restates its position that, under the Treaty of Paris of 1920, Norway has no right to take either measures to restrict access to the waters around Svalbard or enforcement measures with respect to vessels flying the flag of a Member State of the European Community operating in those waters. Enforcement measures should only be taken by the Flag State and any wrongdoing by a vessel from a Member State of the European Community should be prosecuted within the legal system of the Flag State.

\footnotetext{
78 Note Verbale No. 26/04, of 20 July 2004, by the Delegation of the European Commission to Norway and Iceland to the Royal Ministry of Foreign Affairs of Norway (on file with author).

${ }^{79}$ Note Verbale No. 32/09, of 4 September 2009, by the Delegation of the European Commission to Norway and Iceland to the Royal Ministry of Foreign Affairs of Norway (on file with author).

${ }^{80}$ Note Verbale No. 19/11, of 8 July 2011, from the EU Delegation to Norway to the Royal Ministry of Foreign Affairs of Norway (on file with author).
} 
The first paragraph relates to the spatial scope of application of the Spitsbergen Treaty and Norway's designation of the FPZ in 1977. ${ }^{81}$ The words "consistent position" intend to convey that the EU is a persistent objector to Norway's position. ${ }^{82}$ This is also reflected in key EU fisheries enactments. ${ }^{83}$ This part of the EU's position is therefore basically identical to the position of the United Kingdom and other states, as discussed in the previous subsection.

The second paragraph of Note Verbale No. 32/09 focuses more specifically on Norway's legislative and enforcement jurisdiction over fisheries "in the waters around Svalbard". It is submitted that the cited words indicate that the EU's position is not confined to the FPZ but also applies to the territorial waters of Svalbard. As regards legislative jurisdiction, the EU rejects the position that Norway is entitled to take "measures to restrict access". It is important to note that this rejection is not subject to any qualifiers. It would, for instance, have been possible to include terminology to emphasize that the restriction of access must be in accordance with the Spitsbergen Treaty (i.e., equal access), a term such as 'unilateral', a need for consultation or the right of the EU to set 'autonomous' quota when necessary. Moreover, the fact that only these measures are mentioned suggests implicitly that the EU does not object to other fisheries conservation and management measures, presumably as long as they are in accordance with the Spitsbergen Treaty, including that they are non-discriminatory and "suitable". ${ }^{84}$

As regards enforcement jurisdiction, Note Verbale No. 32/09 contests that Norway has any competence whatsoever over Community vessels. Similar to the rejection of legislative jurisdiction, this rejection is not subject to qualifiers. It would, for instance, have been possible to include wording to acknowledge that Norway has enforcement jurisdiction to ensure compliance with measures other than measures to restrict access.

${ }^{81}$ It can be noted that in 1977, of the then nine Member States of the European Communities, Luxembourg was not a party to the Spitsbergen Treaty.

82 Pedersen 2008, note 13 supra, at p. 241 observes that on 19 July 1977, the European Commission issued a Note Verbale to Norway reserving fishing rights for the Member States.

${ }_{83}$ As regards the Table on cod (Gadus morhua) in relation to the Zone "I and IIb" in Council Regulation (EU) No. 57/2011, of 18 January 2011, 'fixing for 2011 the fishing opportunities for certain fish stocks and groups of fish stocks, applicable in EU waters and, for EU vessels, in certain non-EU waters' OJ 2011, L 24/1, at p. 72, the following footnote is included: "The allocation of the share of the cod stock available to the Union in the zone Spitzbergen and Bear Island is entirely without prejudice to the rights and obligations deriving from the 1920 Treaty of Paris." Similar or identical footnotes were included in previous years in the same Regulations.

${ }^{84}$ Cf. Art. 2(2) of the Spitsbergen Treaty. It seems that suitability would, inter alia, require measures to be science-based and taken pursuant to precautionary and ecosystem-based approaches to fisheries management. 
A comparison between the position of the European Commission/EU as reflected in Notes Verbales No. 26/04 and No. 32/09 and that of several EU Member States discussed in the previous subsection reveals significant differences. While this European Commission/EU position clearly focuses specifically on Norway's legislative and enforcement jurisdiction over fishing activities in the maritime zones of Svalbard, it is not clear if the positions of Denmark (and the Faroe Islands), the Netherlands and the United Kingdom also have such a specific focus. Conversely, Portugal and Spain may well have such a specific focus.

This specific focus of the position of the European Commission/EU in these Notes Verbales seems at first glance both logical and appropriate in light of the EU's exclusive competence in that area. However, a more specific position on legislative and enforcement jurisdiction in one substantive area is almost certain to affect the ability to pursue a different position in another substantive area, for instance on offshore hydrocarbon activities. This concern should be seen in light of the fact that the EU and seven EU Member States are currently not party to the Spitsbergen Treaty and that the Treaty intends to apply to the full range of substantive categories and areas of state sovereignty. Whereas the EU and its Member States share competence in some of these areas, there may be areas where the EU has no (explicit) competence. For these reasons several EU Member States have argued in the context of meetings of the European Council's Working Party on the Law of the Sea (COMAR) that the European Commission is not entitled to singlehandedly issue Notes Verbales on fisheries regulation of Svalbard but should at the very least consult those EU Member States that are party to the Spitsbergen Treaty. ${ }^{85}$

The foregoing analysis needs adjustment as it was drafted prior to the European Commission/EU's recently issued Note Verbale No. 19/11, in response to Norway's decision to commence the regulation of targeted fishing for, and by-catch of, haddock in the FPZ of Svalbard in May $2011 .^{86}$ Note Verbale No. 19/11 contains the previously used wording on the EU's "consistent position on the status of the archipelago of Svalbard under the Treaty of Paris of 1920 " but adds the phrase "with regard to fisheries", presumably in light of debates such as those in COMAR discussed above. However, the European Commission did not consult EU Member States that are party to

${ }^{85}$ Cf. para. 6 of a report on the COMAR meeting on 1 June 2010 (on file with author). This para. also notes that the meeting requested the Council's Legal Service to provide an opinion on this matter. At the time of writing, this opinion had been finalized but could not be made available to the author.

${ }^{86}$ See also section 'Species Regulation, including through Catch and Access Restrictions and Allocation' below. 
the Spitsbergen Treaty prior to issuing the Note Verbale. ${ }^{87}$ Moreover, no reference is made to the absence of Norwegian rights to impose access restrictions or exercise enforcement jurisdiction over non-Norwegian vessels. Instead, the EU stipulates in the Note Verbale that

Acceptance by the European Union of fishery regulations proposed by Norway pertaining to the waters around Svalbard has been conditional on the regulations being

- applied in a non-discriminatory manner;

- based on scientific advice; and

- respected by all interested Parties.

While the meaning and purpose of the text after the last bullet is unclear, as a whole the wording suggests that the position of the European Commission/ EU has converged with the positions of the United Kingdom and various other EU Member States. ${ }^{88}$ This conclusion is not affected by the ensuing reasoning of the European Commission/EU, namely that the Regulations on haddock discriminate against vessels of EU Member States; that they are thereby inconsistent with the provisions on equal access and non-discrimination in the Spitsbergen Treaty and-implicitly-thereby not opposable to the EU; and, finally, that the EU therefore feels compelled to determine an autonomous quotum. However, only future Notes Verbales or other official statements by the European Commission, in particular when Community vessels are once again subjected to Norwegian enforcement action in the FPZ of Svalbard, can confirm if such a change in the position of the European Commission/EU has indeed taken place.

\section{Relevant (Sub-)Regional and Bilateral Fisheries Instruments}

\section{Introduction}

This section examines (sub-)regional and bilateral fisheries instruments that are relevant for fisheries regulation in the maritime zones of Svalbard, in particular those that contain provisions that specifically allocate catches to the maritime zones of Svalbard. ${ }^{89}$ It is structured by means of the following subsections:

\footnotetext{
87 Information based on a conversation with a Netherlands official on 29 September 2011.

${ }_{88}$ While Note Verbale No. 19/11 also refers to "specific reservations" in past Notes Verbales, it is submitted that these would have been restated if these were regarded as crucial.

89 Where no official English translation was available - which was the case for many of the relevant instruments- the analysis had to rely on translation by Google Translate.
} 
- NEAFC Convention and Acts by NEAFC;

- Norway-EU Instruments;

- Norway-Faroe Islands Instruments;

- Norway-Greenland Instruments;

- Norway-Iceland Instruments;

- Norway-Russian Federation Instruments;

- Instruments on Norwegian Spring-Spawning (AS) Herring;

- Instruments on North-East Atlantic Mackerel; and

- Instruments on Blue Whiting.

\section{NEAFC Convention and Acts by NEAFC}

The maritime zones of Svalbard are situated in their entirety within the NEAFC Convention Area. ${ }^{90}$ Much of the NEAFC Convention is devoted to the competence of NEAFC. Paragraph (1) of Article 4 stipulates that NEAFC shall perform its functions in order to fulfil the objective set out in Article 2, and paragraph (2) requires that its recommendations take account of a number of considerations, for instance to apply the precautionary approach. Read in conjunction, Articles 5 and 6 show that the competence of NEAFC relates first of all to fisheries conducted beyond "an area under the jurisdiction" of coastal states. This competence therefore relates to straddling fish stocks and discrete high seas fish stocks, but not to shared fish stocks or discrete inshore fish stocks. Pursuant to Article 6, NEAFC also has competence over fisheries conducted within the maritime zones of a coastal state within the

${ }^{90}$ Cf. Art. 1(a) of the NEAFC Convention, note 32 supra. It should be noted that the 'Map of the NEAFC Regulatory Area' posted on the NEAFC Website (<www.neafc.org>, accessed at 19 September 2011) does not treat the territorial waters and FPZ of Svalbard as part of the NEAFC Regulatory Area. The term 'Regulatory Area' is not defined in the NEAFC Convention but in Art. 1(b) of the NEAFC Scheme of Control and Enforcement (as amended at the 29th Annual NEAFC Meeting (2010); version in effect from 5 February 2011) —as "the waters of the Convention Area, which lie beyond the waters under the fisheries jurisdiction of Contracting Parties". However, the Map has been posted on the NEAFC website for illustration only. As it is not formally part of the NEAFC Convention or the NEAFC Scheme of Control and Enforcement and has not otherwise been the subject of a decision by NEAFC, it has no legal status of its own or any bearing on NEAFC's recognition of Norwegian jurisdiction over the maritime zones of Svalbard. The Map has been drawn by the NEAFC Secretariat on the basis of information provided by NEAFC Members on the outer limits of their 200-nm zones. It should be noted that the Map does not show the areas of high seas in the central Arctic Ocean. Steps have been taken to obtain information from Denmark (in relation to Greenland), Norway (in relation to Spitsbergen) and the Russian Federation on the outer limits of their 200-nm zones that extend into the Arctic Ocean within the NEAFC Convention Area (information provided by K. Hoydal, 11 March 2010). 
NEAFC Convention Area, provided the relevant coastal state requests NEAFC to exercise such competence. This competence could relate to straddling fish stocks, shared fish stocks or discrete inshore fish stocks.

As regards the NEAFC Recommendations that were in force for $2010,{ }^{91}$ their full titles indicate that only Recommendation II: 2010 'Redfish in the Irminger Sea' is based partly on Article 6 of the NEAFC Convention and partly on its Article 5.92 None of the other 2010 Recommendations are based partly or entirely on Article $6 .{ }^{93}$ Consequently, as the Irminger Sea does not overlap with the maritime zones of Svalbard, none of the NEAFC Recommendations in force for 2010 applied to the maritime zones of Svalbard. It seems also that older NEAFC Recommendations never applied in this manner to the maritime zones of Svalbard either. ${ }^{94}$

The situation with regard to the NEAFC Recommendations in force for $2011^{95}$ differs from that with those in force for 2010. Both Recommendations 2011 'Redfish in the Irminger Sea' and VI: 2011 'Basking Shark' are clearly based on both Articles 5 and 6 of the NEAFC Convention. ${ }^{96}$ As Recommendation VI: 2011 'Basking Shark' applies throughout the NEAFC Convention Area, it also applies to the maritime zones of Svalbard. Apparently, basking shark currently also occur in the maritime zones of Svalbard. ${ }^{97}$ In addition, the full titles of Recommendations I: 2011 'Blue Whiting' and V: 2011 'Herring' (Norwegian spring-spawning (AS) herring) also include both Articles 5 and 6 and the phrase "NEAFC Convention Area". For 2010, however,

\footnotetext{
${ }^{91}$ On file with author. Unfortunately, at the time of writing the NEAFC website did not contain past NEAFC Recommendations that are no longer in force. Some past NEAFC Recommendations that are no longer in force could be found at <archive.neafc.org $>$.

92 The "Performance Review Panel Report of the North East Atlantic Fisheries Commission, NEAFC" (November 2006), at pp. 17 and 30 notes that this dates back to 1996 (see note 91 supra). See also S. Sen, "The Evolution of High-Seas Fisheries Management in the North-East Atlantic", 35 Ocean \& Coastal Management 85-100 (1997), at pp. 94-95.

93 Reference can nevertheless be made to the 3rd preambular para. and the 4th operative para. of Recommendation VII: 2010 'Spurdog', which are identical and read "Contracting Parties are encouraged to take conservation measures with equal effect within waters under their national jurisdiction". Note also operative para. (5) of Recommendation VIII: 2010 'Extension of Area Closures', which provides: "These closures are without prejudice to any sovereign rights of Coastal States over the continental shelf in accordance with the United Nations Convention on the Law of the Sea, including sovereign rights of Coastal States to exploit sedentary species on the continental shelf."

${ }^{4}$ Information provided by K. Hoydal, 11 March 2010.

${ }_{95}$ Available at <www.neafc.org >, accessed at 23 June 2011.

${ }_{96}$ As regards Recommendation VII: 2011 'Spurdog', reference can be made to the 4th operative para. which reads "Contracting Parties are encouraged to take conservation measures with equal effect within waters under their national jurisdiction" (see also note 93 supra).

97 Information obtained on <www.fishbase.org> on 7 June 2011.
} 
Recommendations I: 2010 'Blue Whiting' and V: 2010 'Herring' were based exclusively on Article 5 and were limited to the "NEAFC Regulatory Area", even though their substance is essentially identical to the 2011 Recommendations. Furthermore, the Recommendations on herring for 2010 and 2011 both refer in their operative paragraphs 3 only to Article $5 .{ }^{98}$ The underlying rationale of this new approach for blue whiting and herring is not entirely clear and may have been agreed rather late during the 2010 Annual NEAFC Meeting. It is worth noting that NEAFC's Rules of Procedure do not elaborate on the procedural requirements for requests pursuant to Article 6 of the NEAFC Convention. All this notwithstanding, NEAFC's 2011 Recommendations for blue whiting and herring are explicitly intended to constitute practice of NEAFC competence under Article 6 of the NEAFC Convention. For the purpose of this article, this is in particular relevant for herring, as these also occur in commercially significant quantities in the maritime zones of Svalbard. Blue whiting currently also occur there, ${ }^{99}$ but apparently not in commercially significant quantities. ${ }^{100}$

It is submitted that Norway is entitled to make an explicit request pursuant to Article 6 of the NEAFC Convention in relation to the maritime zones of Svalbard because it is currently generally accepted that these maritime zones are 'areas under the jurisdiction' of Norway. However, in view of the continuing disagreement on the spatial scope of the Spitsbergen Treaty, it seems very unlikely that Norway will actually exercise this entitlement. If Norway were to do so, other Members of NEAFC could interpret it as an attempt to bolster the Norwegian position on the spatial scope of the Spitsbergen Treaty. An entirely different interpretation would be possible too, namely that such a Norwegian request would recognize the need for multilateral instead of unilateral solutions and thereby constitute a departure from Norway's current position on the spatial scope of the Spitsbergen Treaty. It is submitted that the latter interpretation is likely to attract the broadest support, including from within the Norwegian administration. Thus, unless the Norwegian administration would support a new position on the spatial scope of the Spitsbergen Treaty, an explicit Norwegian request pursuant to Article 6 of the NEAFC Convention in relation to the maritime zones of Svalbard is not likely to be forthcoming.

As an aside, reference can be made to parallels between the NEAFC Convention and the OSPAR Convention. ${ }^{101}$ The definition of the OSPAR Maritime

98 The Recommendations on blue whiting for 2010 and 2011 do not refer to either Art. 5 or 6.

99 Information obtained on <www.fishbase.org> on 7 June 2011.

100 Based on email from G. van Balsfoort to the author in June 2010.

101 Convention for the Protection of the Marine Environment of the North-East Atlantic, 
Area as defined in Article 1(a) of the OSPAR Convention is identical to the NEAFC Convention Area as defined in Article 1(a) of the NEAFC Convention. ${ }^{102}$ In November 2009 Norway nominated - in the context of the OSPAR Convention-three marine protected areas (MPAs) off Svalbard. ${ }^{103}$ The outer limits of the MPAs coincide with the outer limits of the territorial sea and together cover most of the territorial waters of Svalbard. ${ }^{104}$ In its formal nomination, Norway specifically repeated its position on the spatial scope of application of the Spitsbergen Treaty, namely that "The treaty applies to the islands and the territorial waters stretching out to $12 \mathrm{~nm}$ from the baseline". ${ }^{105}$ The Summary Record of the relevant OSPAR meeting contains no indication that any of the other OSPAR Members intervened on this issue. ${ }^{106}$ It should be noted, however, that Summary Records are not intended to serve as comprehensive accounts of debates in plenary and that the issue may still have arisen. Likewise, the Spitsbergen Treaty, as well as the specific issue of its spatial application, may have come up in other OSPAR meetings even though this is not reflected in OSPAR documents.

\section{Norway-EU Instruments}

Bilateral cooperation between Norway and the EU takes place in the framework of the 1980 Agreement on fisheries between the European Economic Community and Norway (1980 Norway-EU Agreement). ${ }^{107}$ The Agreement does not refer explicitly to Svalbard or its maritime zones. Pursuant to its Article 11, the Agreement applies "on the one hand, to the territories in which

Paris, 22 September 1992. In force 25 March 1998, <www.ospar.org>. Annex V, Sintra, 23 September 1998. In force 30 August 2000; amended and updated text available at $<w w w$ .ospar.org>.

102 Likewise, the OSPAR Commission does not have an official map of the OSPAR maritime area either. The Map included in the Summary Record of the 2006 OSPAR Commission Meeting is meant for illustrative purposes only.

103 Cf. OSPAR doc. MASH 09/5/6-E, 3 November 2009, 'Nomination of MPAs around Svalbard and Bjørnøya to the OSPAR network of MPAs' (Norway).

${ }_{104}$ Cf. OSPAR doc. MASH 09/5/6, note 103 supra, at pp. 3, 10 and 17. Attention should also be drawn to the fact that the MPA around Bjørnøya seems to extend the full $12 \mathrm{~nm}$ seaward even though the EEZ of mainland Norway lies within $12 \mathrm{~nm}$ of Bjørnøya (see note 27 supra and accompanying text).

105 Cf. OSPAR doc. MASH 09/5/6, note 103 supra, at pp. 4, 11 and 18.

106 See OSPAR doc. MASH 09/9/1, 'Summary Record', at para. 5.1. The Summary Record of the February 2009 meeting of the Biodiversity Committee-where Norway announced its intention to make the MPA nominations-does not indicate that a discussion on this point took place either (cf. OSPAR doc. BDC 09/11/1, 'Summary Record', at para. 5.5).

107 OJ 1980, No. L 226/48. 
the Treaty establishing the European Economic Community is applied and under the conditions laid down in that Treaty and, on the other hand, to the territory of the Kingdom of Norway". Reference can also be made to its Article 1 , which refers to each party's "area of fisheries jurisdiction extending up to 200 nautical miles" and its Article 10, which contains the following broad non-prejudicial clause: "Nothing contained in this Agreement shall affect or prejudice in any manner the views of either Party with respect to any questions relating to the law of the sea."

Notwithstanding this non-prejudicial clause, however, the annual bilateral consultations pursuant to the 1980 Norway-EU Agreement never explicitly relate to the maritime zones of Svalbard and the Agreed Records also do not explicitly mention them. Access by EU vessels pursuant to this Agreement is exclusively confined to the Norwegian EZ, which therefore excludes the maritime zones of Svalbard as well as of Jan Mayen. ${ }^{108}$ As regards Svalbard, this is a direct result of the positions of several EU Member States and the European Commission/EU on the spatial scope of application of the Spitsbergen Treaty, as well as on the entitlements to resources based on the applicability of the equal access and non-discrimination provisions of the Spitsbergen Treaty in conjunction with the historic track record in relevant fisheries. It would be inconsistent with these positions to negotiate access for EU vessels to the maritime zones of Svalbard per se, including in exchange for access for Norwegian vessels to EU waters. It should nevertheless be pointed out that in some broader negotiation processes involving also the EU and Norway, the EU seems less concerned about the implications of grouping the maritime zones of Svalbard together with other areas under Norwegian fisheries jurisdiction. ${ }^{109}$

There is currently no bilateral fisheries agreement between the EU and Norway that relates specifically to the maritime zones of Svalbard and there also seems to be no interest within the European Commission or Norway to commence a negotiation process for such an agreement. A few years ago, there was apparently some support within the European Commission to commence negotiations between the EU and Norway to formalize the current status quo

108 E.g., Agreed Record of Fisheries Consultations between Norway and the European Union for 2011 (Bergen, 4 December 2010. On file with author.), Annex VII, section III(1)(A) refers to "Norwegian Economic Zone". Moreover, Table 3 entitled '2011 Quotas to the EU of Norwegian Exclusive Stocks' contains quotas for Arcto-Norwegian cod, Arcto-Norwegian haddock, saithe, Greenland halibut (by-catches), and others (by-catches) that can presumably be taken within those parts of the Norwegian EZ that lie within ICES (International Council for the Exploration of the Sea) Areas I and II. The Agreed Records for 2008-2010 are similar.

109 See for instance the subsection on 'Instruments on Norwegian Spring-Spawning (AS) Herring'. 
as part of an agreement to disagree. Apparently, Norway did not support such negotiations. ${ }^{110}$

\section{Norway-Faroe Islands Instruments}

Bilateral fisheries consultations between Norway and the Faroe Islands take place in the context of a 1979 Agreement on reciprocal fishing rights. ${ }^{111}$ The Minutes from bilateral consultations for 2006-2010 112 indicate that the Faroe Islands had access to the FPZ of Svalbard for North-East Arctic cod and a fixed tonnage of other species as by-catch-mainly redfish and Greenland halibut - within the third-state quota agreed between Norway and Russia for the FPZ of Svalbard; presumably within the Joint Norwegian-Russian Fisheries Commission. ${ }^{113}$ The Minutes also reflect that fisheries access exists for shrimp in both the territorial waters and the FPZ of Svalbard. ${ }^{114}$ The provision in the Minutes on shrimp refers to an Appendix to the Minutes that contains a Faroese statement on Norway's regulation of shrimp fishing in Svalbard's territorial waters and FPZ. ${ }^{115}$ In this statement the Faroe Islands objects to Norway's use of the reference period 1990-1995 for the purpose of restricting access by means of a maximum number of fishing days. The view that this reference period is discriminatory is accompanied by several arguments. The statement also contains wording that indicates that the Faroese position on the Spitsbergen Treaty is similar to that of the United Kingdom (see above). In addition, it specifically notes the need to resolve the shrimp issue by means of consultation and thereby objects to Norway's unilateral approach.

The situation for 2011, however, was very different from the years 20062010 due to the failure of the EU, the Faroe Islands, Iceland and Norway to agree on an overall total allowable catch (TAC) and national allocations for North-East Atlantic mackerel for 2011 (see the subsection 'Instruments on

\footnotetext{
${ }^{110}$ Interview between the author and an official from the European Commission on 15 October 2009.

111 Agreement between Norway and the Faroese Islands on Reciprocal Fishing Rights, Tórshavn, 7 February 1979. In force 9 September 1980; Treaties of Norway (NT), Vol. V, pp. 475-476.

112 E.g., Protokoll fra Drøftelser mellom Norske og Farøyske Myndigheter i Oslo, 12-13 Januar 2010, om Gjensidige Fisherettigheter i 2010 (Google translate: "Minutes from discussions between Norwegian and Faroese Governments in Oslo, 12-12 January 2010, on reciprocal fishing rights in 2010". Text on file with author). The Minutes of the discussions for 20062009 are on file with the author also.

113 Cf. Sec. I(C)(1) of the 2006-2010 Minutes. See also note 191 infra and accompanying text.

114 Cf. Sec. I(C)(2) of the 2006-2010 Minutes.

115 See note 178 infra and accompanying text.
} 
North-East Atlantic Mackerel'). For Norway, resolution of the North-East Atlantic mackerel impasse was a precondition for negotiating a bilateral fisheries agreement with the Faroe Islands. Despite the absence of such a bilateral agreement, however, Faroese vessels fished in the maritime zones of Svalbard for, inter alia, herring, cod and shrimp, during 2011. Conversely, at the time of writing no Faroese fishing had taken place in the maritime zones of Jan Mayen and mainland Norway in 2011. ${ }^{116}$

It is submitted that the impasse on North-East Atlantic mackerel has revealed the risks and shortcomings of the Faroese approach on Svalbard in the context of fisheries. Unlike the EU, Iceland and the Russian Federation, the Faroe Islands have not managed to separate-let alone insisted on thisthe issue of fisheries access to the maritime zones of Svalbard from the issue of bilateral exchanges of quota and access with Norway. ${ }^{117}$ By not insisting that these two fundamentally different issues are dealt with in formally separate processes/meetings, the Faroe Islands unwittingly supported the Norwegian position that fisheries access to the FPZ of Svalbard does not depend on being a party to the Spitsbergen Treaty or historic track records. This weakness in the Faroese position now seems to be rectified by the continuation of its fishing activities in the maritime zones of Svalbard. It seems also likely that future bilateral fisheries consultations and instruments with Norway will be adjusted to take the aforementioned observations into account.

\section{Norway-Greenland Instruments}

Bilateral fisheries consultations between Norway and Greenland take place in the context of a 1979 Agreement on mutual fishery relations. ${ }^{118}$ The Minutes of bilateral consultations for $2007-2010^{119}$ are structured along several

\footnotetext{
116 Based on information provided to the author during a conversation with an official of the Faroese government on 30 June 2011.

117 The results obtained by the Faroe Islands under the coastal state arrangements on herring (see the subsection 'Instruments on Norwegian Spring-Spawning (AS) Herring') can be used as an example as well.

118 Agreement between Greenland/Denmark and Norway concerning Mutual Fishery Relations, Copenhagen, 9 June 1992. In force provisionally with retroactive effect from 24 September 1991 and definitely on 4 March 1994, 1829 United Nations Treaty Series 223 (1994). See also T. Gudmundsson, "Cod War on the High Seas. Norwegian-Icelandic Dispute over 'Loophole' Fishing in the Barents Sea", 64 Nordic Journal of International Law 557-573 (1995), at p. 558.

119 Protokoll fra Møte $i$ det Norsk-Grønlandske Kontaktutvalg, Oslo 14-15 januar 2010 (Unofficial translation: "Minutes from a meeting of the Norwegian-Greenlandic Contact Group, Oslo, 14-15 January 2010”. On file with author). The Minutes for 2007-2009 are on file with the author also.
} 
sections. The section 'Greenlandic Fishing in Norway's Economic Zone' is the most relevant for the purpose of this article and contains subsections on the Norwegian Economic Zone North and South of $62^{\circ} \mathrm{N}$, respectively. ${ }^{120}$ The subsection 'In the Norwegian Economic Zone North of $62^{\circ} \mathrm{N}$ ' lists access for North-East Arctic cod, haddock, Arctic saithe and some by-catch of redfish and Greenland halibut. As regards cod, haddock and saithe, however, a footnote specifies that the quota can also be fished in the FPZ of Svalbard but that this 'element' only applies as long as the 2003 Trilateral Capelin Agreement ${ }^{121}$ is in force. The section on 'Other Provisions' touches, inter alia, on Greenlandic fishing for shrimp in the maritime zones of Svalbard. While Norway emphasizes that its 1996 Regulations ${ }^{122}$ will be enforced, Greenland refers to its position on these Regulations as expressed to Norwegian authorities on 11 September 1997. The core elements of the agreements for 2010 have been extended for $2011 .{ }^{123}$

Apart from shrimp, therefore, this bilateral arrangement does not acknowledge or provide Greenland direct access to the FPZ of Svalbard but makes this dependent on (1) the continuation of the Trilateral Capelin Agreement and (2) access to the Norwegian EZ, obtained by exchanging quota and access. $^{124}$

Moreover, in the context of the 2003 Trilateral Capelin Agreement, Norway and Greenland adopted bilateral arrangements in $2003^{125}$ that allow Greenlandic fishermen to fish quota for Norwegian spring-spawning (AS) herring, obtained through bilateral arrangements with the Faroe Islands, within the FPZ of Svalbard. ${ }^{126}$ Moreover, Norway also allows demersal

120 For 2011, Norway has implemented these through the 'Regulations of 13 December 2010, No. 1596, relating to the regulation of fisheries for vessels flying the flag of Greenland in the Norwegian economic zone in 2011'.

121 Agreement between Iceland, Greenland / Denmark and Norway on the capelin stock in the waters between Greenland, Iceland and Jan Mayen, Reykjavik, 8 July 2003. In force provisionally on 8 July 2003 (on file with author). The agreement appears to be currently in force (cf. Meld. St. Nr. 26 (2010-2011), Fiskeriavtalane Noreg har inngått med andre land for 2011 og fisket etter avtalane i 2009 og 2010 (Unofficial translation: "Fisheries agreements Norway has signed with other countries for 2011 and fishing for agreements in 2009 and 2010), at p. 8 .

122 See note 178 supra.

123 Cf. Press Release Nr. 90/2010, of 8 December 2010 (available at <www.regjeringen.no/nn/ $\mathrm{dep} / \mathrm{fkd} /$ pressesenter/Pressemeldingar>, accessed 20 September 2010).

${ }_{124}$ As regards haddock, this is confirmed by Sec. 3(2) of the Regulations of 11 May 2011, No. 485, note 86 supra.

125 Bilateral arrangement between Greenland and Norway on mutual fishing access on the capelin stock in the waters between Greenland and Jan Mayen season 2003/2004, 2 July 2003 (on file with author).

126 Cf. the Minutes to the bilateral arrangement of 2 July 2003, note 125 supra. 
quota relating to the area north of $62^{\circ} \mathrm{N}$, obtained by Greenland from not only Norway but also from the Russian Federation, to be taken in the FPZ of Svalbard. ${ }^{127}$

\section{Norway-Iceland Instruments}

There is no bilateral fisheries instrument between Norway and Iceland that acknowledges or provides Icelandic fisheries access to the maritime zones of Svalbard. ${ }^{128}$ Several bilateral agreements and arrangements nevertheless exist, including one of the two bilateral protocols under the trilateral 1999 Loophole Agreement between Iceland, Norway and the Russian Federation ${ }^{129}$ and the bilateral access arrangements on herring (see below). The last sentence of Article 4 of the Loophole Agreement stipulates that "The quotas referred to in article 2 shall be taken in the exclusive economic zones and the Parties will refrain from any claims for additional fishing possibilities on that stock".

127 Ibid., and based on a telephone conversation between E.J. Molenaar and a Greenlandic official on 20 September 2010. Cooperation between Denmark/Greenland and the Russian Federation takes place in the context of the Agreement between the Government of the Kingdom of Denmark and the Local Government of Greenland, on the one hand, and the Government of the Russian Federation, on the other hand, concerning Mutual Fishery Relations between Greenland and the Russian Federation (Copenhagen, 7 March 1992. In force provisionally on 7 March 1992 and definitely on 16 October 1992, 1719 United Nations Treaty Series 89 (1993)).

128 See also Gudmundsson, note 118 supra.

129 Agreement between the Government of Iceland, the Government of Norway and the Government of the Russian Federation Concerning Certain Aspects of Co-operation in the Area of Fisheries, St. Petersburg, 15 May 1999. In force 15 July 1999; 41 Law of the Sea Bulletin 53 (1999); Protocol between the Government of Iceland and the Government of the Russian Federation under the Agreement between the Government of Iceland, the Government of Norway and the Government of the Russian Federation concerning Certain Aspects of Cooperation in the Area of Fisheries St. Petersburg, 15 May 1999. In force 15 July 1999; 14 International Journal of Marine and Coastal Law 488-490 (1999); <faolex.fao.org>; and Protocol between the Government of Norway and the Government of Iceland under the Agreement between the Government of Iceland, the Government of Norway and the Government of the Russian Federation concerning Certain Aspects of Co-operation in the Area of Fisheries St. Petersburg, 15 May 1999. In force 15 July 1999; 41 Law of the Sea Bulletin 56 (1999) <faolex.fao.org>. According to Meld. St. Nr. 26 (2010-2011), note 121 supra, at p. 8, the Loophole Agreement and its two bilateral protocols were still in force for 2011 (see also Art. 12 of the Loophole Agreement and the information at <www.regjeringen.no/nb/dep/fkd/ tema/fiske_og_fangst/internasjonalt_samarbeid_om_fiskeri/fiskerisamarbeidet-med-island. html?id=437336>, accessed 20 September 2011). For 2011, Norway has implemented this by means of the 'Regulations of 9 December 2010, No. 1565, relating to the regulation of fishing by vessels flying the Icelandic flag in the economic zone and the fisheries zone around Jan Mayen in 2011'. 
In conjunction with the Norwegian-Icelandic Protocol to the Loophole Agreement, Norway regards this as an Icelandic assurance that the latter will not ask for access to cod in the FPZ of Svalbard. ${ }^{130}$

\section{Norway-Russian Federation Instruments}

Bilateral cooperation on fisheries between Norway and the Russian Federation takes place predominantly within the Joint Norwegian-Russian Fisheries Commission established by the bilateral 1975 Framework Agreement. ${ }^{131}$ This Agreement was adopted against the background of the failure to resolve the delimitation of the two states' maritime zones in the Barents Sea and was complemented by two other agreements, namely the 1976 Mutual Access Agreement ${ }^{132}$ and the 1978 Grey Zone Agreement. ${ }^{133}$ The latter provided, inter alia, for parallel Norwegian and Russian flag state jurisdiction in the so-called 'grey zone'. This zone consisted of: one area that was indisputably part of the maritime zones of Norway; one area that was indisputably part of the maritime zones of the Russian Federation; one area claimed by both states; and one area claimed only by Norway. ${ }^{134}$ With the entry into force of the 2010 Murmansk Treaty, ${ }^{135}$ the 1978 Grey Zone Agreement will no

\footnotetext{
${ }^{130}$ Cf. the information obtained at the website in the previous footnote. As Art. 1 of the Norway-Icelandic Protocol provides that "Iceland shall not undertake fishing for Barents Sea capelin for the period for which the Agreement is in force", this would also seem to apply to capelin.

131 Agreement between the Government of the Kingdom of Norway and the Government of the Union of Soviet Socialist Republics on Co-operation in the Fishing Industry, Moscow, 11 April 1975. In force 11 April 1975; 983 United Nations Treaty Series 7 (1975). It should be noted that the Art. III of the 1975 Agreement speaks of the "Mixed Commission". More generally on the Joint Commission see O.S. Stokke, Disaggregating International Regime Effectiveness: Theory, Method, Governance (Cambridge (MA), MIT Press, forthcoming in 2012).

132 Agreement between the Government of the Union of Soviet Socialist Republics and the Government of the Kingdom of Norway Concerning Mutual Relations in the Field of Fisheries, Moscow, 15 October 1976. In force 21 April 1977; 1157 United Nations Treaty Series 146 (1980).

133 Avtale mellom Norge og Sovjetunionen om en midlertidig praktisk ordning for fisket i et tilstotende omrade i Barentshavet (Agreement between Norway and the Soviet Union on provisional practical arrangements on fishing in an adjacent area of the Barents Sea), Oslo, 11 January 1978. In force 11 January 1978; Overenskomster med fremmede stater (1978), 436. The 1978 Grey Zone Agreement was initially valid until 1 July 1978 but was renewed every year for a duration of one year.

134 See, inter alia, O.S. Stokke, "The Loophole of the Barents Sea Fisheries Regime", in: Governing High Seas Fisheries: The Interplay of Global and Regional Regimes, O.S. Stokke (ed.) (Oxford: Oxford University Press, 2001), pp. 273-301, at p. 274.

135 See note 22 supra.
} 
longer be needed and the abovementioned parallel jurisdiction will therefore cease to exist. ${ }^{136}$

The 2010 Murmansk Treaty deals with fisheries in Article 4 and its Annex I, entitled 'Fisheries matters'. Article 4 provides:

1. The fishing opportunities of either Party shall not be adversely affected by the conclusion of the present Treaty.

2. To this end, the Parties shall pursue close cooperation in the sphere of fisheries, with a view to maintain their existing respective shares of total allowable catch volumes and to ensure relative stability of their fishing activities for each of the stocks concerned.

3. The Parties shall apply the precautionary approach widely to conservation, management and exploitation of shared fish stocks, including straddling fish stocks, in order to protect the living marine resources and preserve the marine environment.

4. Except as provided for in this Article and in Annex I, nothing in this Treaty shall affect the application of agreements on fisheries cooperation between the Parties.

Whereas paragraphs (1) and (2) are aimed at maintaining the status quo on the allocation of fishing opportunities, paragraph (3) changes the status quo by an undertaking to be bound by the precautionary approach, even though the treaty neither defines nor operationalizes this. This obligation will thus modernize and change the obligations of the two states under the 1975 Framework Agreement. Annex I on 'Fisheries matters' consists of four articles, whose primary aim is to emphasize the maintenance of the status quo, including the 1975 Framework Agreement, the 1976 Mutual Access Agreement and the competence of the Joint Norwegian-Russian Fisheries Commission.

It is significant that nothing in the title, Preamble or body of the 1975 Framework Agreement is explicitly devoted to its spatial scope generally or with respect to the law of the sea's maritime zones. The Agreement-and thereby the mandate of the Joint Commission-is therefore not confined exclusively to the maritime zones of the two states or to the Barents Sea. Fisheries in adjacent waters-namely the Arctic Ocean, Greenland Sea and Norwegian Sea-as well as fisheries in high seas pockets—namely the Barents Sea Loophole and the high seas pocket in the Central Arctic Oceantherefore fall in principle within the purview of the Joint Commission as

136 The 2010 Murmansk Treaty does not mention the 1978 Grey Zone Agreement at all. This was probably deemed unnecessary because the 1978 Grey Zone Agreement has to be renewed annually to remain in force (see note 133 supra). The Agreement will therefore simply not be renewed. 
well. ${ }^{137}$ The full title of the 2010 Murmansk Treaty confirms that bilateral cooperation will relate to both the Barents Sea and the Arctic Ocean.

Something which should not be left unmentioned here-even though it cannot be elaborated upon-is the rather unique practice of the Joint Commission in managing fishing in the Barents Sea Loophole without the formal involvement of third states and entities (e.g., the EU). ${ }^{138}$ These states and entities were encouraged to discontinue, or not to commence, fishing for particular species in the Barents Sea Loophole and thereby not to exercise their entitlements under international law to fish in the high seas and to be involved in high seas fisheries management. ${ }^{139}$ In return, Norway and the Russian Federation granted fisheries access to their maritime zones and discontinued withholding benefits such as access to ports. The trilateral 1999 Loophole Agreement discussed in the subsection 'Norway-Iceland Instruments' above is a result of this approach. ${ }^{140}$ An interesting question is how the Joint Commission's practice in this regard will evolve in response to the rapidly changing Arctic due to global climate change, for instance: (1) if currently unregulated fisheries (e.g., for shrimp) in the Loophole become unsustainable, ${ }^{141}$ (2) if the zonal attachment of regulated fish stocks to the Loophole increases significantly, or (3) if new commercially viable fisheries_-including for species

137 Para. 14.1 of the Protocol of the 2009 Meeting of the Commission stipulates: "The parties agreed to prepare a draft request to ICES for ongoing monitoring of the distribution in the Arctic Ocean of the stocks managed by the Joint Norwegian-Russian Fisheries Commission" (Google translation). A request by the two chairmen of the Joint Commission was submitted to ICES by a letter dated 21 June 2010. ICES responded in June 2011 that it "is possible to monitor the geographic distribution of these stocks in the ice-free parts of the Arctic Ocean once a year, using existing survey methodology. This could be coordinated by existing ICES expert groups" (Special Request Advice June 2011, subject 'Monitoring of Arctic Ocean fish stocks'; on file with author).

138 Another example constitutes the bilateral management of Australia and New Zealand on the South Tasman Rise (for a discussion see E.J. Molenaar, "The South Tasman Rise Arrangement of 2000 and other Initiatives on Management and Conservation of Orange Roughy", 16 International Journal of Marine and Coastal Law 77-118 (2001).

139 These entitlements are, inter alia, laid down in Art. 116 of the LOS Convention and Art. 8(3) of the Fish Stocks Agreement.

${ }_{140}$ See in this context R.R. Churchill, "The Barents Sea Loophole Agreement: A 'Coastal State' Solution to a Straddling Stock Problem”, 14 International Journal of Marine and Coastal Law 467-483 (1999). It is interesting that Churchill notes on p. 471 that Iceland rejected an earlier proposal by Norway and the Russian Federation for a dedicated regime for the Loophole.

${ }_{141}$ At the time, Churchill 1999, note 140 supra, at p. 473 concluded that such fishing was of no real significance. 
currently subject to NEAFC Recommendations-arise in the Loophole or the high seas pocket in the Arctic Ocean. ${ }^{142}$

Similar to the 1975 Framework Agreement, the 1976 Mutual Access Agreement does not define its spatial scope. The latter's Preamble nevertheless mentions that "a substantial proportion of the living resources of the Norwegian Sea and the Barents Sea represent a unified ecosystem". Reference is also made to the "Atlantic area" and it is noted that "the Norwegian Government has introduced legislation to extend Norway's fisheries jurisdiction to cover a zone of 200 nautical miles". The reciprocal access provided by the 1976 Mutual Access Agreement relates to

the area beyond the limit of 12 national miles measured from the applicable baselines in which [the relevant Contracting Party] is engaged in the management of stocks of fish and other living resources, including their conservation, and the regulation of fishing. ${ }^{143}$

It is submitted that this wording is intended to have a similar meaning as 'areas of fisheries jurisdiction'. As the FPZ of Svalbard was established only in $1977,{ }^{144}$ the wording was not drafted with the differences between the 200-nm zones from the Norwegian mainland and Svalbard in mind. While Norway is likely to take the position that the FPZ of Svalbard is covered by the 1976 Mutual Access Agreement, the Russian Federation probably takes the position that it is not because access thereto is provided by the Spitsbergen Treaty. The records of the Joint Commission do at any rate not refer to the granting of access for Russian vessels to the FPZ of Svalbard. ${ }^{145}$ Moreover, similar to the practice within other bilateral and multilateral consultations discussed in this section, agreement on the TAC and allocation is followed by agreements on mutual access. ${ }^{146}$

${ }_{142}$ See in this regard also the interesting discussion by Churchill 1999, note 140 supra, at pp. 479-480 and 482-483.

143 Art. 1.

144 See note 19 supra.

145 See the Appendices 6 to the Protocols of the 2008-2010 Meetings of the Joint Commission (on file with author).

146 These agreements on mutual access are made pursuant to Art. 2(b) of the 1976 Mutual Access Agreement. See, e.g., Appendix 6 to the Protocol of the 2010 Meeting of the Joint Commission, whose Table I deals with Russian access to the Norwegian Economic Zone but specifies in relation to Norwegian spring-spawning (AS) herring (Norsk vargytende sild) that it can be fished in areas of Norwegian jurisdiction. See also the access specifications on blue whiting (kolmule). 
The focus of the Joint Commission's work is on demersal species, including cod (Norwegian Arctic cod and coastal cod), (North-East Arctic) haddock and Greenland (North-East Arctic) halibut, but its work also relates to (Barents Sea) capelin, harp seals, king crab and (other) relatively small fish stocks. For most species, the Joint Commission determines TACs based on advice provided by the International Council for the Exploration of the Sea (ICES) on joint request by the two Members. The Joint Commission also strives to coordinate the scientific research of its two Members. As it is a bilateral body, decision-making within the Joint Commission is obviously by consensus.

In addition to allocating fishing opportunities and access between the two Members-including for stocks whose TACs have been established through other processes ${ }^{147}$-, the Joint Commission has also allocated fishing opportunities to third states on cod, Greenland halibut and haddock. ${ }^{148}$ Of these three species, third states can in principle only target cod in the maritime zones of Svalbard. ${ }^{149}$ As regards cod, for 2011 third states were allocated 97,494 tonnes-about $14.6 \%$ of the TAC—of which 27,560 tonnes can be caught in the 'Svalbard area' (including presumably both the FPZ and territorial waters). ${ }^{150}$ As regards Greenland halibut, for 2011 third states were allocated 600 tonnes_ $4 \%$ of the TAC—all of which can be taken in the 'Svalbard area'. ${ }^{151}$

\section{Instruments on Norwegian Spring-Spawning (AS) Herring}

The multilateral coastal state agreements on Norwegian spring-spawning (AS) herring — which contain TACs and allocations (national quota)—are commonly complemented by NEAFC Recommendations ${ }^{152}$ and a series of bilateral

\footnotetext{
147 E.g., blue whiting (see note 146 supra).

148 The basis for these allocations could be the stocks' occurrence in the Loophole, in the maritime zones of Svalbard, or in both.

149 As regards Greenland halibut this seems consistent with Norwegian Regulations (see notes 197 and 198 infra and accompanying text). As regards haddock, Greenland is entitled to conduct a targeted fishery for haddock in the FPZ of Svalbard on the basis of its access to haddock in the Norwegian EZ (see note 199 infra and accompanying text).

${ }^{150}$ Cf. Appendices 3 and 4 to the Protocol of the 2010 Meeting of the Joint Commission (on file with author). For 2010 third states were allocated 83,910 tonnes-about $14.7 \%$ of the TAC_ - of which 23,720 tonnes could be caught in the 'Svalbard area' (cf. Appendices 3 and 4 to the Protocol of the 2009 Meeting of the Joint Commission).

${ }^{151} \mathrm{Ibid}$. For 2010 third states were allocated 600 tonnes - $4 \%$ of the TAC—of which half could be fished in the 'Svalbard area'.

152 See subsection 'NEAFC Convention and Acts by NEAFC' supra.
} 
access arrangements. For the years 2007-2011, multilateral agreements were concluded between the EU, the Faroe Islands, Iceland, Norway and the Russian Federation. ${ }^{153}$ The bilateral access arrangements between Norway and the four others for 2007-2011 $1^{154}$ indicate that vessels from the EU, the Faroe Islands and the Russian Federation ${ }^{155}$ had access to "areas under Norwegian fisheries jurisdiction north of $62^{\circ} \mathrm{N}$ " (see also Table 1 below). This phrase comprises the Norwegian EZ, the Fishery Zone of Jan Mayen and the maritime zones of Svalbard.

Icelandic vessels, however, only had/have access to the "Fishery Zone around Jan Mayen or [...] the Norwegian Economic Zone north of $62^{\circ} \mathrm{N}$ ". ${ }^{156}$ Notwithstanding this stipulation, since 2007 the annual Regulations that prohibit fishing for herring in the FPZ of Svalbard ${ }^{157}$ are amended each year around July/August by Regulations that allow fishing for herring-in a designated area and during a specified period_also by vessels that have access to herring in other areas under Norwegian fisheries jurisdiction. ${ }^{158}$ Iceland nevertheless regards this conditional access to the FPZ as inconsistent with the Spitsbergen Treaty and has regularly objected to the Regulations as a matter of principle. ${ }^{159}$

For a period of several years immediately before 2007, no multilateral coastal state agreements on herring could be adopted and Norway regulated

153 As regards 2011, these are laid down in the 'Agreed Record of Conclusions of Fisheries Consultations on the Management of the Norwegian Spring-Spawning (Atlanto-Scandian) Herring Stock in the North-East Atlantic for 2010', London, 21 October 2010 (on file with author). The Agreed Records for 2007-2010 are on file with author also.

154 All on file with author.

155 For 2008-2011. For 2007, the bilateral arrangement between Norway and the Russian Federation uses the terms "Norwegian Economic Zone, the Fisheries Zone around Jan Mayen, and the Fisheries Protection Zone around Svalbard".

156 Norway has implemented this by means of the Regulations of 9 December 2010, No. 1565, note 129 supra.

157 For 2011 these are the 'Regulations of 2 December 2010, Nr. 1522, relating to a prohibition against fishing for Norwegian spring-spawning herring in the Fisheries Protection Zone around Svalbard in 2011', whose Sec. 2 contains a general prohibition. As regards the territorial waters of Svalbard, Sec. 2 of the 'Regulations of 2 December 2010, No. 1521, relating to a prohibition against fishing for Norwegian spring-spawning herring in the territorial and internal waters of Svalbard in 2011' contains a general prohibition. These Regulations seem to be renewed each year.

158 Applicable at the time of writing were the 'Regulations of 13 July 2011, No. J-137-2011, amending the Regulations of 2 December 2010, No. 1522, relating to a prohibition against fishing for Norwegian spring-spawning herring in the Fisheries Protection Zone around Svalbard in 2011' (available at Juridiske Meldinger (legal messages) J-137-2011, at <www .fiskeridir.no>; see No. J-166-2010 (now discontinued) for the previous year).

159 Information provided to the author by an Icelandic official on 21 June 2011. 
the herring in the FPZ of Svalbard by means of a TAC and an 'Olympic' fishery. ${ }^{160}$ This caused the Icelandic government to prepare a legal action against Norway before the International Court of Justice (ICJ). ${ }^{161}$ The successful adoption of the 2007 coastal state agreement made Iceland decide not to pursue that option, however. ${ }^{162}$

A question that immediately arises is why Norway pursues a different approach in its bilateral access arrangements with Iceland compared to those with the EU, the Faroe Islands and the Russian Federation. The most likely explanation is that Iceland did not have a historic track record for fishing for herring in the maritime zones of Svalbard when Norway commenced regulation there. As will be discussed in more detail in the section 'Species Regulation, including through Catch and Access Restrictions and Allocation ' below, for regulated species Norway has chosen the existence of a historic track record as the criterion for the de facto implementation of the provisions on equal access and non-discrimination of the Spitsbergen Treaty in Svalbard's FPZ. Norway's legal position is of course that the Spitsbergen Treaty and the entitlements it contains are not applicable to the FPZ. Unqualified acceptance of Icelandic fisheries access in the FPZ of Svalbard would have undermined the method and policy of reliance on historic track records and would thereby have undermined Norway's position on the spatial scope of application of the Spitsbergen Treaty.

Table 1 below gives some more insight into the intricate coastal state negotiations on herring by displaying the allocations of the EU, the Faroe Islands, Iceland and the Russian Federation, as well as the agreements on access to Norwegian waters. A range of outcomes is possible, with access for all or part of the allocation to all or part of areas under Norwegian fisheries jurisdiction, all depending on what can be offered to Norway in return. While the Russian Federation and Iceland (even though indirectly (see above)) have ensured that they are entitled to fish $100 \%$ of their allocation in the maritime zones of Svalbard, the EU and the Faroe Islands have not obtained, or insisted on, $100 \%$, even though that would have been consistent with their position on the spatial scope of application of the Spitsbergen Treaty.

\footnotetext{
160 This means that the fishery is closed as soon as the TAC has been caught.

161 The competence of the ICJ might have been based on a 1930 bilateral agreement on peace-

ful dispute settlement (cf. Churchill and Ulfstein 2010, note 13 supra, at p. 589).

${ }^{162}$ Information provided to the author by an Icelandic official on 21 June 2011.
} 
Table 1. Allocations of and Access to Herring in Norwegian (NO) Waters for 2009-2011

\begin{tabular}{lcccccc}
\hline & \multicolumn{2}{c}{2011} & \multicolumn{2}{c}{2010} & \multicolumn{2}{c}{2009} \\
& Allocation & $\begin{array}{c}\text { Access to } \\
\text { NO waters }\end{array}$ & Allocation & $\begin{array}{c}\text { Access to } \\
\text { NO waters }\end{array}$ & Allocation & $\begin{array}{c}\text { Access to } \\
\text { NO waters }\end{array}$ \\
\hline EU & 64,319 & $57,887^{\mathrm{a}}$ & 96,543 & $86,889^{\mathrm{a}}$ & 106,959 & $96,263^{\mathrm{a}}$ \\
\hline Faroe Islands & 50,981 & $30,103^{\mathrm{a}}$ & 76,523 & $45,185^{\mathrm{a}}$ & 84,779 & $50,061^{\mathrm{a}}$ \\
& & $22,348^{\mathrm{b}}$ & & $33,599^{\mathrm{b}}$ & & $37,224^{\mathrm{b}}$ \\
\hline Iceland & 143,359 & $143,359^{\mathrm{c}}$ & 215,183 & $215,183^{\mathrm{c}}$ & 238,399 & $238,399^{\mathrm{c}}$ \\
& & $26,676^{\mathrm{d}}$ & & $40,041^{\mathrm{d}}$ & & $44,361^{\mathrm{d}}$ \\
\hline $\begin{array}{l}\text { Russian } \\
\text { Federation }\end{array}$ & 126,661 & $126,661^{\mathrm{a}}$ & 190,121 & $190,121^{\mathrm{a}}$ & 210,633 & $210,633^{\mathrm{a}}$ \\
\hline
\end{tabular}

${ }^{a}$ in areas under Norwegian fisheries jurisdiction north of $62^{\circ} \mathrm{N}$

$\mathrm{b}$ in the Norwegian Economic Zone

${ }^{c}$ in the Fishery Zone around Jan Mayen or in the Norwegian Economic Zone north of $62^{\circ} \mathrm{N}$

$d$ in the Norwegian Economic Zone north of $62^{\circ} \mathrm{N}$.

\section{Instruments on North-East Atlantic Mackerel}

The distributional range of North-East Atlantic mackerel seems to overlap to some extent with the maritime zones of Svalbard, but probably not sufficiently to sustain commercially viable target fisheries. ${ }^{163}$

The trilateral coastal state agreements between Norway, EU and the Faroe Islands on North-East Atlantic Mackerel for 2007-2009, ${ }^{164}$ and presumably also between 2000-2006, are not complemented by bilateral access arrangements. The trilateral agreements for 2007-2009 nevertheless seem

\footnotetext{
163 Information obtained on <www.fishbase.org> on 27 July 2011.

164 Agreed Record of Conclusions of Fisheries Consultations between the European Community, the Faroe Islands and Norway on the Management of Mackerel in the North-East Atlantic for 2007 (Edinburgh, 24 October 2006; on file with author), Agreed Record of Conclusions of Fisheries Consultations between Norway, the European Community and the Faroe Islands on the Management of Mackerel in the North-East Atlantic for 2008 (Oslo, 30 October 2007; on file with author) and Agreed Record of Conclusions of Fisheries Consultations between the Faroe Islands, the European Community and Norway on the Management of Mackerel in the North-East Atlantic for 2009 (London, 31 October 2008; on file with author).
} 
to suggest that only Norway and the EU would negotiate bilateral access arrangements. ${ }^{165}$

No coastal state agreement could be adopted for 2010 due to, inter alia, disagreement as to whether or not Iceland should be allowed to participate in the negotiations as a coastal state. In this situation, Norway and the EU adopted the 2010 EU-Norway Agreed Record on North-East Atlantic Mackerel, ${ }^{166}$ which was negotiated in conjunction with the overall 2010 Agreed Record under the 1980 Norway-EU Agreement, ${ }^{167}$ and also covers access. The 2010 Agreed Record on Mackerel consistently uses "EU waters" and "Norwegian waters". While no explicit reference is made to the FPZ of Svalbard, the Agreed Record provides EU access to Norwegian waters of ICES Division IIa, which partly overlaps with the FPZ. In addition, NEAFC adopted a Recommendation on Mackerel for 2010 by postal vote, ${ }^{168}$ which does not set a joint TAC but requires members to set (unilateral) catch limits for their mackerel fisheries on the high seas.

For 2011 no coastal state agreement could be adopted either, despite formal acceptance of Iceland as a coastal state and many rounds of negotiations. All that could be agreed is a NEAFC Recommendation that appears to be identical to the one for $2010 .{ }^{169}$ The EU and Norway nevertheless managed to agree on national catch limits and access agreements and arrangements for 2011. ${ }^{170}$ Where the Agreed Record for 2010 uses "Norwegian waters", however, the Agreed Record for 2011 uses the words "Norwegian Economic Zone", which does not comprise the maritime zones of Svalbard. The reason for this changed wording is not clear, but it could simply reflect that, as has been noted above, target fisheries for mackerel are currently not commercially viable in the maritime zones of Svalbard. This may change in the future, however, and a discussion on possible scenarios has therefore been included in the subsection 'Unregulated Fisheries' below.

\footnotetext{
165 See para. 4 of all the Annexes I to the Agreed Records for 2007/2009.

166 Agreed Record of Conclusions of Fisheries Consultations between the European Union and Norway on the Management of Mackerel in the North-East Atlantic, Brussels, 26 January 2010 (on file with author).

167 See, inter alia, section 5.2 of the 2010 EU-Norway Agreed Record on North-East Atlantic Mackerel.

168 Recommendation for Conservation and Management Measures for North-East Atlantic Mackerel in the NEAFC Regulatory Area in 2010.

169 Recommendation by the North-East Atlantic Fisheries Commission, adopted by postal vote, in accordance with Article 5 of the NEAFC Convention, for Conservation and Management Measures for North-East Atlantic Mackerel in the NEAFC Regulatory Area in 2011.

170 Agreed Record of Conclusions of Fisheries Consultations between the European Union and Norway on the Management of Mackerel in the North-East Atlantic for 2011, Copenhagen, 10 December 2010 (on file with author).
} 


\section{Instruments on Blue Whiting}

As noted above, blue whiting currently also occur in the maritime zones of Svalbard, but apparently not (yet) in commercially significant quantities. ${ }^{171}$

The multilateral coastal state agreements on blue whiting between the EU, Faroe Islands, Iceland and Norway for 2007-2011 ${ }^{172}$ are commonly complemented by NEAFC Recommendations ${ }^{173}$ and bilateral access arrangements. Access arrangements that are relevant for the purpose of this article are those between Norway and the EU and between Norway and the Faroe Islands. No bilateral access agreements on blue whiting seem to have been adopted between Norway and Iceland. ${ }^{174}$ The bilateral access agreements for 20082010 between Norway and the EU, and between Norway and the Faroe Islands, provide the EU and the Faroe Islands with access to the Norwegian Economic Zone and the Jan Mayen Fishery Zone, and thereby not to the maritime zones of Svalbard. ${ }^{175}$ These arrangements seem to have been extended for 2011, presumably along the same lines. ${ }^{176}$

The question which arises in view of these arrangements is why the phrase "areas under Norwegian fisheries jurisdiction", which is used, inter alia, in the access arrangements on herring (see above), is not used instead. Perhaps it is simply because, as has been mentioned above, target fisheries for blue whiting are currently not commercially viable in the maritime zones of Svalbard. This may change in the future, however, and a discussion on possible scenarios has therefore been included in the subsection 'Unregulated Fisheries' below.

\footnotetext{
171 See notes 99 and 100 supra and accompanying text.

172 E.g., Agreed Record of Conclusions of Fisheries Consultations between the Faroe Islands, the European Union, Iceland and Norway on the Management of Blue Whiting in the NorthEast Atlantic in 2011, London, 19 October 2010 (on file with author).

173 See subsection 'NEAFC Convention and Acts by NEAFC' supra.

174 Cf. Press Release Nr. 72/2010, of 19 October 2010, at <www.regjeringen.no>.

175 E.g., Agreed Record of Conclusions of Fisheries Consultations between Norway and the European Community on the Management of the Fisheries on the Stock of Blue Whiting in the North-East Atlantic for 2010, London, 22 October 2009 (on file with author), para. 2 of the Annex; and Agreement between Norway and the Faroe Islands on the Management of Blue Whiting in the North-East Atlantic, London, 22 October 2009 (on file with author).

${ }^{176}$ As Press Release Nr. 72/2010, note 176 supra, observes that Norwegian vessels continue to have access in the maritime zones of the EU and the Faroe Islands, it can be presumed that access to the Norwegian maritime zones is granted to the EU and the Faroe Islands in return.
} 


\section{Species Regulation, Including through Catch and Access Restrictions and Allocation}

\section{Regulated Fisheries}

How and by whom the TAC for different regulated species (stocks) in the maritime zones of Svalbard is established, as well as how and on which rationale the TAC is allocated, including by means of providing or restricting access, varies considerably. A preliminary issue is whether or not it matters that a stock is transboundary or not. It is submitted that this really depends on a state's or entity's position on the spatial scope of the Spitsbergen Treaty. Arguing on the basis of Norway's position, a unilateral approach would be justified for a stock whose distributional range is confined to the FPZ of Svalbard. However, this argument would not be valid for a stock which occurs partially in Svalbard's territorial waters and partially in its FPZ, but not seaward thereof. States and entities that disagree with Norway's position are not likely to see a justification for a unilateral approach in either of these cases.

A distinction can be made between species that are regulated in a predominantly unilateral fashion by Norway and species whose regulation is largely or entirely multilateral. At the latter end of the spectrum is Norwegian springspawning (AS) herring, whose TACs and allocations are determined by the coastal states, as well as within NEAFC, based on scientific advice provided by ICES. The allocation criteria presumably include historic track records and zonal attachment. The subsection on 'Instruments on Norwegian SpringSpawning (AS) Herring' devotes more attention to various regulatory issues. Moreover, blue whiting and North-East Atlantic mackerel are at the same end of the spectrum as herring, but are discussed in the subsection 'Unregulated Fisheries' below.

At the other end of the spectrum is the regulation of shrimp, for which Norway has so far unilaterally determined the TAC, the basis for allocation and how fishing opportunities are allocated. ${ }^{177}$ Norway's Regulations acknowledge the right of vessels from Canada, EU Member States, the Faroe Islands, Greenland, Iceland, Russia and Norway to fish for shrimp in the maritime zones of Spitsbergen. ${ }^{178}$ Regulatory measures for shrimp are based on scientific

177 See the brief overview on the regulation of the shrimp fishery in E. Guijarro Garcia (ed.), S.A. Ragnarsson, S.A. Steingrímsson, D. Nævestad, H.P. Haraldsson, J.H. Fosså, O.S. Tendal and H. Eiríksson, Bottom Trawling and Scallop Dredging in the Arctic. Impacts of Fishing on Non-target species, Vulnerable Habitats and Cultural Heritage (Nordic Council of Ministers, Copenhagen: 2007), at pp. 198-200.

178 Cf. the 'Regulations of 19 July 1996, No. 735, relating to regulatory measures for the 
advice provided by the Norwegian Institute for Marine Research (IMR). ${ }^{179}$ Nevertheless, Norway held informal or formal prior consultations with relevant states and entities, presumably to inform itself of their views in order to arrive at decisions that are, as much as possible, regarded as fair and equiTable $2 y$ all or most. ${ }^{180}$ The current allocation key is based on a historic track record ${ }^{181}$ within a certain reference period and is allocated by means of a maximum number of fishing vessels and a maximum number of fishing days for individual states. ${ }^{182}$ Canada and Greenland are currently not using their allocations $^{183}$ and the Faroe Islands object to the reference period determined by Norway. ${ }^{184}$ Greenland and Iceland also objected to the Norwegian shrimp regulation at the time ${ }^{185}$ and based on the responses by the European

shrimp fisheries in the territorial and internal waters of Svalbard', last amended on 31 August 2005; the 'Regulations of 19 July 1996, No. 726, relating to the regulation of shrimp fishing in the fisheries protection zone around Svalbard', last amended in 2006; and separate Regulations for Canada, the Faeroe Islands, Greenland, Iceland, the European Union, Russia and Norway for the territorial waters and the FPZ of Svalbard (as regards the EU see note 182 infra). As regards Lithuania, see also notes 52-55 supra and accompanying text. See also the 'Regulations of 11 July 1997, No. 784, relating to registration of vessels that are to take part in shrimp fisheries in the Fisheries Protection Zone around Svalbard and the territorial and internal waters of Svalbard', last amended in 2006; and 'Regulations of 20 September 2000, No. 1697, relating to fishing for shrimp-closure of areas in the Fisheries Protection Zone around Svalbard, Svalbard's territorial waters and internal waters'. These Regulations stipulate that area closures and changes thereto will be announced in Juridiske Meldinger (legal messages) posted on the website of the Norwegian Fisheries Directorate <www.fiskeridir.no>. J-94-2011 contains the most recent area closures, valid from 20 May 2011.

179 See also Guijarro Garcia et al., note 177 supra at pp. 200-204.

180 See the responses by the European Commission mentioned in note 186 infra and accompanying text.

181 Cf. Sec. 2 of the Regulations of 19 July 1996, No. 735, note 178 supra, whose first sentence reads "Only vessels of countries that have traditionally fished for shrimps in the territorial and internal waters of Svalbard or in the Fisheries Protection Zone around Svalbard may fish for shrimps in the territorial and internal waters of Svalbard."

182 See, e.g., the "Regulations of 19 July 1996, No. 742, relating to fishing for shrimps using vessels from member states of the European Communities in the territorial and internal waters of Svalbard', last amended on 31 August 2005. The Regulations allow 12 vessels to fish for a total of 1080 days per calendar year in the territorial waters and FPZ combined.

${ }^{183}$ Cf. O.S. Stokke, "The Loophole of the Barents Sea Fisheries Regime", in: Governing High Seas Fisheries: The Interplay of Global and Regional Regimes, O.S. Stokke (ed.) (Oxford, Oxford University Press: 2001), pp. 273-301, at p. 301, n. 116. As regards Canada, this was confirmed by the Canadian Department of Foreign Affairs and International Trade in an email to the author on 15 July 2010. As regards Greenland, this was confirmed by an official of the Greenlandic administration in a telephone conversation with the author on 20 September 2010 .

184 See subsection 'Norway-Faroe Islands Instruments' above.

185 As regards Greenland, see note 122 supra and accompanying text. As regards Iceland, this is based on information provided to the author by an Icelandic official on 21 June 2011. 
Commission to written questions by members of the European Parliament on the regulation of shrimp fishing in the maritime zones of Svalbard, ${ }^{186}$ it seems that the European Commission objects to certain aspects of Norwegian regulation as well.

As regards scallops, Norwegian Regulations do not set a TAC but-for scallop fishing in the FPZ - designate a closed area and prescribe a minimum size. ${ }^{187}$

As regards capelin, copepods, krill and other zooplankton, Norway has unilaterally prohibited targeted fishing. With regard to capelin this prohibition applies to both Norwegian and foreign vessels, ${ }^{188}$ but for copepods, krill and other zooplankton, it applies only to Norwegian vessels. ${ }^{189}$

186 E.g., Written Question P-2160/00 by Carmen Fraga Estévez (PPE-DE) to the Commission, 'Proposed allocation of shrimp catch possibilities in Svalbard waters', OJ 2001, E 81/162; Written Question E-2196/00 by Carmen Fraga Estévez (PPE-DE) to the Commission, 'Proposed allocation of fishing opportunities to the Community fleet in the waters of the Svalbard archipelago', OJ 2001, E 89/159; Written Question P-2974/00 by Carmen Fraga Estévez (PPE-DE) to the Commission, 'The Commission's criteria for allocating fishing opportunities in the waters of the Svalbard archipelago', OJ 2001, E 113/223; Written Question E-1037/02 by Daniel Varela Suanzes-Carpegna (PPE-DE) to the Commission, 'Svalbard prawn fishing', OJ 2002, E 229/172; Written Question E-1015/04 by Daniel Varela SuanzesCarpegna (PPE-DE) to the Commission, 'Shrimp fishing in Svalbard', OJ 2004, C 88E/271272; Written Question E-3581/03 by Daniel Varela Suanzes-Carpegna (PPE-DE) to the Commission, 'Shrimp fishing in Svalbard', OJ 2004, C 078 E/830-831; and Written Question E-1015/04 by Daniel Varela Suanzes-Carpegna (PPE-DE) to the Commission, 'Shrimp fishing in Svalbard', OJ 2004, C 88E/271-272.

187 Cf. 'Regulations of 10 January 1989, No. 12, to regulate the catch of scallops (Chlamys islandica) in the Fisheries Protection Zone around Svalbard', last amended in 1999. See also Guijarro Garcia et al., note 177 supra, at pp. 31 and 35, where it is observed that the scallop fishery was closed in Svalbard waters in 1995 due a collapse of the stock.

188 'Regulations of 2 December 2010, No. 1519, relating to a prohibition against fishing for capelin in the territorial and internal waters of Svalbard in 2011'; and 'Regulations of 2 December 2010, No. 1523, relating to a prohibition against fishing for capelin in the Fisheries Protection Zone of Svalbard in 2011'. Both sets of Regulations seem to be renewed each year. Secs. 2 of both contain a general prohibition.

189 Regulations of 28 March 2006, No. J-68-2006, 'prohibiting fishing for copepods, krill and other zooplankton' (Legal notice, available at <www.fiskeridir.no $>$ ). These Regulationswhich apply pursuant to Sec. 1 to Norwegian vessels within the North-East Atlantic, in ICES areas I-XIV-have attracted attention in the literature for their specific relevance for the maritime zones of Spitsbergen. R.G. Tiller, "New Resources and Old Regimes: Will the Harvest of Zooplankton Bring Critical Changes to the Svalbard Fisheries Protection Zone?" 40 Ocean Development \& International Law 309-318 (2009), in particular at p. 312. Nevertheless, the company Calanus holds a license to catch a certain amount of zooplankton for research purposes in the Norwegian Economic Zone (see <www.calanus.no>; accessed 23 September 2010 and email to the author on 27 September 2010). Harvesting in the maritime zones of Spitsbergen would thus not be allowed under the license. 
As regards redfish, Norwegian Regulations prohibit targeted fishing but allow a $15 \%$ by-catch. ${ }^{190}$

As regards North-East Arctic cod, the TAC and allocation are determined by the Joint Norwegian-Russian Fisheries Commission based on advice from ICES. The allocation key is presumably based on a combination of zonal attachment and historic track records. Norway's Regulations-which apply exclusively to the FPZ of Svalbard—acknowledge the right of Norwegian and Russian vessels to fish North-East Arctic cod in the FPZ, provided they remain within the quota allocated to them. ${ }^{191}$ Distinct from this category is the category of vessels from states that have traditionally fished for North-East Arctic cod in the FPZ, which are specified to be vessels from EU Member States and the Faroe Islands. These also have a right to fish, provided they remain within the quota allocated to them. ${ }^{192}$ A subsequent category is that of vessels from states that have fisheries access for cod in the Norwegian EZ, ${ }^{193}$ which would seem to include both Iceland ${ }^{194}$ and Greenland. ${ }^{195}$

The situation for Greenland halibut and haddock is to some extent similar to that of North-East Arctic cod, as the TACs and allocations are also determined by the Joint Norwegian-Russian Fisheries Commission based on advice from ICES, and the allocation key for targeted fisheries is presumably based on a combination of zonal attachment and historic track records. ${ }^{196}$

As regards Greenland halibut, Norwegian Regulations specify that Norwegian and Russian vessels that are permitted to fish in the Norwegian EZ can fish in the territorial waters and FPZ of Svalbard. ${ }^{197}$ While Russian vessels

190 Cf. Secs. 1 and 2 of the 'Regulations of 17 December 2009, No. 1592, relating to fishing for redfish in the Fisheries Protection Zone around Spitsbergen' and the 'Regulations of 17 December 2009, No. 1592, relating to fishing for redfish in the Fisheries Protection Zone around Spitsbergen'.

191 Cf. Sec. 3(1) of the 'Regulations of 2 December 2010, No. 1520, relating to fishing for cod in the Fisheries Protection Zone around Svalbard in 2011'. These Regulations seem to be renewed every year, with different allocations.

192 Cf. Sec. 3(2)-(4) of the Regulations of 2 December 2010, No. 1520, note 191 supra.

193 Cf. Sec. 4 of the Regulations of 2 December 2010, No. 1520, note 191 supra. Sec. 5 also allows $10 \%$ by-catch.

194 Cf. Sec. 2(a) of the Regulations of 9 December 2010, No. 1565, note 129 supra.

195 See subsection 'Norway-Greenland Instruments' supra.

196 Cf. Ulfstein 1995, note 5 supra, at p. 451.

197 Cf. 'Regulations of 2 December 2010, No. 1518, relating to a prohibition against fishing for Greenland halibut in the territorial and internal waters of Svalbard'; and 'Regulations of 2 December 2010, No. 1524, relating to a prohibition against fishing for Greenland halibut in the Fisheries Protection Zone around Svalbard in 2011'. Both sets of Regulations seem to be renewed or amended each year. It should be noted that whereas the official Norwegian texts use "Russian" in Secs. 3 of both sets of Regulations, the English translation at <www.fiskeridir .no/english/fisheries/regulations > uses "foreign" instead. 
have therefore strictly speaking only conditional access to the maritime zones of Svalbard, in view of the practice as a whole this is unlikely to form a practical restriction. Vessels of all states that are permitted to target other species are allowed to have a certain percentage of by-catch, ${ }^{198}$ presumably as long as they remain within the allocation for third states as agreed by the Joint NorwegianRussian Fisheries Commission.

With respect to haddock, Norwegian Regulations specify that Norwegian and Russian vessels may target haddock in the FPZ, that Greenlandic vessels can target haddock in the FPZ pursuant to, and within, their haddock quota in the Norwegian EZ north of $62^{\circ} \mathrm{N}$ and that vessels from EU Member States and the Faroe Islands are entitled to a $15 \%$ by-catch of haddock in catches of other species. ${ }^{199}$

\section{Unregulated Fisheries}

The discussion in the previous subsection provided various examples where Norwegian species regulation does not apply uniformly to all of Svalbard's maritime zones. For instance, the Regulations on scallops, North-East Arctic cod, and haddock only apply to the FPZ but not to Svalbard's territorial waters, and the general prohibition in the Regulations on copepods, krill and other zooplankton applies only to Norwegian vessels. Such lack of uniformity can have potentially significant implications in light of the circumstance that Norwegian legislation does not contain a general provision that stipulates that fishing activities in Svalbard's maritime zones are prohibited unless they are permitted. ${ }^{200}$ Instead, individual sets of species regulations commonly start out with a prohibition on targeting a particular species, which is then subsequently qualified by one or more exceptions (permissions). ${ }^{201}$ Norway's regulatory system for Svalbard's maritime zones therefore allows, in principle, 'unregulated fisheries' to continue or develop. It needs to be emphasized,

\footnotetext{
198 Cf. Secs. 4 of both sets of Regulations.

199 'Regulations of 11 May 2011, No. 485, relating to fishing for haddock in the Fisheries Protection Zone around Svalbard in 2011'.

200 As regards the Norwegian EZ, a general prohibition on fishing by foreigners is contained in Sec. 3 of the Act of 17 December 1976, No. 91, note 19 supra. If Norway would have preferred to have such a provision, the Regulations of 3 June 1977, No. 6, note 19 supra, on the FPZ and the 'Regulations of 28 April 1978, No. 20, concerning the regulation of fishing and hunting etc. in Svalbard's territorial waters and internal waters' (last amended in 2008) would probably have been the most logical candidates.

201 E.g., as regards cod (Sec. 2 of the Regulations of 2 December 2010, No. 1520, note 191 supra) and as regards Greenland halibut (Sec. 2 of the Regulations of 2 December 2010, No. 1518, note 197 supra). Conversely, regulations such as those on scallops (Regulations of 10 January 1989, No. 12, note 187 supra) allow fishing except in certain areas.
} 
however, that the notion of 'unregulated fisheries' used here is intended to have a specific and limited meaning, as these fisheries must obviously comply with all applicable non-species-specific enactments, for instance those on bottom fisheries and minimum mesh sizes. ${ }^{202}$ Finally, it should be acknowledged that Norway's approach on unregulated fisheries is far from unique. A wide majority of states currently follows the same approach.

Partly unregulated species include blue whiting and North-East Atlantic mackerel. Current Norwegian regulations explicitly allow licensed Norwegian vessels to fish for blue whiting and mackerel in the FPZ of Svalbard. ${ }^{203}$ These regulations are not applicable to foreign vessels, however, and in the absence of an overarching prohibition elsewhere in Norwegian legislation, as well as the equal access and non-discrimination provisions in the Spitsbergen Treaty, it can be assumed that fisheries for these species are unregulated fisheries $v i s-\grave{a}$-vis foreign vessels. These foreign vessels, however, may still be subject to regulation by their own flag states, for instance through overall, non-areaspecific catch restrictions derived from multilateral agreements or unilateral undertakings.

It should be recalled here that the bilateral access agreements on blue whiting and mackerel discussed in the respective subsections above do not explicitly provide access to the maritime zones of Svalbard. Arguably, if target fisheries for blue whiting and mackerel would become commercially viable in the maritime zones of Svalbard in the future, states parties to the Spitsbergen Treaty could take the position that they are entitled to such access pursuant to the Treaty. Such a position could — for both species—be taken by the EU, the Faroe Islands and Iceland based on their capacity as coastal states. The Russian Federation (for both species) and Greenland (for blue whiting) could take a similar position in view of their high seas allocations pursuant to NEAFC Recommendations. ${ }^{204}$

The soundness of the preceding analysis is corroborated by the scenario that triggered Norway to enact the Regulations on haddock in May 2011,205 after

\footnotetext{
202 See, inter alia, the 'Regulations of 1 July 2011, No. 755, relating to bottom fishing activities in the Economic Zone of Norway, the fisheries zone around Jan Mayen and the Fisheries Protection Zone around Svalbard'; the 'Regulations of 21 September 1994, No. 881, on mesh size, by-catch, and minimum size, etc. when fishing in the Fisheries Protection Zone around Svalbard', last amended on 5 January 2011; and the 'Regulations of 21 September 1994, No. 882, on mesh size, by-catch, and minimum size, etc. when fishing in the territorial and internal waters of Svalbard', last amended on 5 January 2011.

203 Cf. Sec. 2 of the 'Regulations of 16 December 2010, No. 1700, relating to the regulation of fishing for blue whiting in 2011'; and Sec. 2(1) of the 'Regulations of 20 December 2010, No. 1777, relating to the regulation of fishing for mackerel in 2011'.

${ }^{204}$ For blue whiting for 2010-2011 and for mackerel for 2009-2011.

205 Note 199 supra.
} 
it had become apparent that certain vessels flying the flag of EU Member States had begun targeting haddock in Svalbard's FPZ in or around 2009. ${ }^{206}$ This targeted fishery appears to have become commercially viable due to higher abundance generally and also specifically in the maritime zones of Svalbard. Prior to the 2011 Regulations on haddock, Norwegian and Russian vessels were bound to non-area-specific catch restrictions agreed within the Joint Norwegian-Russian Fisheries Commission. For other vessels, however, by-catch and targeted catch of haddock in the maritime zones of Svalbard constituted an unregulated fishery. ${ }^{207}$ As explained above, the 2011 Regulations on haddock only allow vessels of EU Member States and the Faroe Islands a $15 \%$ by-catch of haddock but not an allocation for a targeted fishery. Norway apparently justified this on account of the absence of a historic track record. ${ }^{208}$ The European Commission/EU took the view that this distinction amounts to a violation of the provisions on equal access and non-discrimination in the Spitsbergen Treaty. ${ }^{209}$ It seems indeed that the Norwegian reasoning is at least partially inconsistent, because if a targeted fishery for haddock was not commercially viable prior to 2009, Norwegian and Russian catches prior to then must have derived primarily from by-catch as well.

\section{Conclusions}

The core of this article relates to the spatial scope of the Spitsbergen Treaty. Norway's position is that it ends at the outer limit of the territorial sea. Seaward thereof the normal law of the sea regime applies, thus entitling Norway to a continental shelf and EEZ and their associated sovereign rights and jurisdiction. However, despite claiming a right to establish a regular EEZ and to exercise therein the associated sovereign rights and jurisdiction in the usual fashion, Norway has chosen not to make use thereof. Instead, Norway established a Fisheries Protection Zone (FPZ) for Svalbard in 1977.

It is significant that there do not seem to be any other states that currently support the Norwegian position on the spatial scope of the Spitsbergen Treaty. While some states - for instance the United States-have reserved their rights on the issue, the positions of a sizeable group consisting of, inter alia, Denmark (and the Faroe Islands), Iceland, the Netherlands, the United Kingdom-and presumably now also the Russian Federation and Spain-are

206 Cf. Norwegian Letter of 9 August 2011, note 44 supra, pp. 5-6.

207 Ibid., at p. 6.

${ }^{208}$ Ibid., at p. 5.

209 Cf. Note Verbale No. 19/11, note 80 supra, at p. 1. 
essentially similar, namely that Norwegian sovereignty over Svalbard entitles Norway to establish seaward of the territorial sea the usual maritime zones recognized by the international law of the sea and to exercise therein the associated sovereign rights and jurisdiction. However, as the Spitsbergen Treaty applies to these maritime zones, this imposes restrictions on Norwegian sovereign rights and jurisdiction, and most importantly the provisions on equal access and non-discrimination. It is submitted that this position is more in line with what seems to have been the basic intention of the negotiators of the Spitsbergen Treaty, namely to replace the pre-existing terra nullius status of Svalbard with Norwegian sovereignty, but to maintain the pre-existing status quo where (especially) relevant, possible and practical. ${ }^{210}$ Conversely, if Norway's position would be upheld, this would make Norway 'more equal than' other contracting parties. ${ }^{211}$

Prior to issuing its Note Verbale No. 19/11 on 8 July 2001, the position of the European Commission/EU diverged significantly from the positions of the states just mentioned. The difference consisted of a specific focus on fisheries regulation, challenging in particular Norwegian rights to impose access restrictions or exercise enforcement jurisdiction over non-Norwegian vessels. This specific focus seems at first glance both logical and appropriate in light of the EU's exclusive competence in that area. However, a more specific position on legislative and enforcement jurisdiction in one substantive area is almost certain to affect the ability to pursue a different position in another substantive area, for instance on offshore hydrocarbon activities. This concern should be seen in light of the fact that the EU and seven EU Member States are currently not party to the Spitsbergen Treaty and that the Treaty intends to apply to the full range of substantive categories and areas of state sovereignty. Whereas the EU and its Member States share competence in some of these areas, there may be areas where the EU does not have (explicit) competence.

As already alluded to, the position of the European Commission/EU as reflected in Note Verbale No. 19/11 recently seems to have been adjusted. It not only clarifies that the position is confined to the domain of fisheries but also makes no reference to the specific objections on Norwegian rights to impose access restrictions or exercise enforcement jurisdiction over non-Norwegian

${ }^{210}$ Cf. Churchill and Ulfstein 1992, note 13 supra, at pp. 46 and 49. In their joint article of 2010, however, they attribute less weight to this factor and are eventually unable "to reach a clear-cut and unequivocal conclusion" on the spatial scope of the Treaty (cf. Churchill and Ulfstein 2010, note 13 supra, at p. 593).

211 Norway's distinction from other contracting parties also derives from Norway's uncontested title to sovereignty over Svalbard. 
vessels. The position of the European Commission/EU therefore seems to have converged with the positions of the United Kingdom and various other EU Member States mentioned above. Future Notes Verbales or other official statements by the European Commission, in particular when EU vessels are once again subjected to Norwegian enforcement action in the FPZ of Svalbard, can confirm if such a change in the position of the European Commission/EU has indeed taken place. This depends, inter alia, on the positions of Portugal and Spain on Norwegian enforcement jurisdiction in the FPZ of Svalbard. These two states and the Russian Federation have frequently challenged such jurisdiction in the past. The Russian Federation did so very recently, in September 2011, in response to the arrest of the Russian trawler Sapphire II by the Norwegian Coast Guard. ${ }^{212}$

While the legal positions of Norway and several other states and the European Commission/EU on the spatial scope of the Spitsbergen Treaty are relatively straightforward, this article's analysis of (sub-)regional and bilateral fisheries instruments and Norwegian legislation has shown that state practice is much more diffuse. The examined practice involved seeks to reconcile legal positions on the spatial scope of the Spitsbergen Treaty with a raft of other interests. Prominent among these are the need to safeguard good bilateral and multilateral relationships and regimes, as well as the substantial commercial interests in the continued functioning of (sub-)regional and bilateral agreements on reciprocal fisheries access and exchanges of fishing opportunities. The competence and practice of the Joint Norwegian-Russian Fisheries Commission with regard to the Loophole in the Barents Sea undoubtedly played a significant role and is expected to continue to do so. Providing third states with access to maritime zones of coastal states as compensation for not fishing in the Loophole and thereby not challenging the competence of the Joint Commission, is an approach that also appears in various formats with respect to Svalbard's FPZ.

Direct access to the FPZ of Svalbard-rather than through access to the Norwegian EZ-for states other than Norway and the Russian Federation seems to be predominantly or exclusively determined by historic track records. This raises the question as to whether this is consistent with the provisions on equal access and non-discrimination in the Spitsbergen Treaty. It seems that a majority of states parties has no historic track records and, apart from Lithuania, no non-parties have these either. While Article 10 of the Spitsbergen Treaty imposes no substantive restrictions on adherence, new parties will thus not be able to exercise their rights of equal access and treatment with regard

${ }^{212}$ See the news release dated 7 October 2011 at <www.barentsobserver.com>. 
to marine capture fisheries. It is submitted that even though the criterion of historic track records is used extensively by coastal states and entities of the North-East Atlantic Ocean, ${ }^{213}$ this does not necessarily mean that they are barred from advocating access based on other criteria in the context of the Spitsbergen Treaty. A ruling by an international court or tribunal could provide clarity on this, but so far states or entities either did not have the opportunity for such a course of action or did not feel the need for this in light of the various other interests identified above. If historic track records are not relied on exclusively or at all, which criterion or criteria should (also) be applied, and in what manner? Proposals for alternatives are unlikely to come from the states and entities that are currently involved in fishing in the maritime zones of Svalbard as they probably prefer the status quo, despite its shortcomings.

As 35 years have now passed since the establishment of the FPZ in 1977, it seems extremely unlikely that Norway will ever establish an EEZ and exercise the associated sovereign rights and jurisdiction in the EEZ and continental shelf in a manner that would completely disregard the applicability of the Spitsbergen Treaty. However, despite 35 years of de facto recognition of the Treaty's applicability, Norway's de jure position seems still tenable. Some time ago Iceland proposed that a Conference of Parties be convened to discuss the issue of the spatial scope of the Spitsbergen Treaty in light of the disagreement on this issue between Norway and most other contracting parties. ${ }^{214}$ The Spitsbergen Treaty itself does not contain provisions on such meetings or on review or amendment procedures. It would seem that if a Conference of Parties merely held discussions, not all contracting parties would have to participate in order for such discussions to have sufficient legitimacy and authority $v i s-\grave{a}$-vis the Spitsbergen Treaty. Norwegian participation would nevertheless be essential for that. Norway is likely to be concerned that it might be isolated in such a Conference, however, and would only participate if its cost-benefit analysis of the current status quo and a Conference of Parties-and plausible future developments for both, in particular with regard to the potential for offshore hydrocarbon activities - concludes that the latter is preferable. The design of the objective, agenda and rules of procedure of such a Conference could play a crucial role in this respect.

Separate attention should also be devoted to the issue of unregulated species examined above. The enactment of the Norwegian Regulations on haddock illustrates, inter alia, that vessels have an incentive to build track records

${ }^{213}$ Cf. Ulfstein, note 5 supra, at p. 452 with regard to the (now) EU.

${ }^{214}$ Based on correspondence between the author and an Icelandic official in June 2011. 
for unregulated species. Such an incentive could, for instance, lead to catches of blue whiting and mackerel in the maritime zones of Svalbard, regardless of whether these are due to targeted fishing or by-catch. But as is widely known, however, building track records can also rapidly lead to over-exploitation or even 'boom-bust' scenarios, for instance when regulatory response time is high due to inertia or a deadlock within, or the absence of, a regulatory authority, or when stocks are highly vulnerable to over-exploitation (e.g., some deepsea fish stocks due to the small size of the stock, low reproduction rate, etc.). Particularly troublesome are unregulated fisheries for new species, in new areas or that use new fishing technology or techniques. In the context of the rapid pace of climate-induced change in the Arctic, including the receding and thinning sea-ice, such concerns need to be carefully considered. Reference can in this context be made to the decision by the United States to prohibit commercial fishing in the EEZ off Alaska in the Arctic Ocean "until information improves so that fishing can be conducted sustainably and with due concern to other ecosystem components" ${ }^{215}$ It is therefore hoped that Norway will consider a similar approach and thereby a de facto prohibition of unregulated fisheries, at least for those parts of the maritime zones of Svalbard where fishing has so far not been possible due to sea-ice coverage.

215 Cf. Sec. E.S. 1.2, at p. ES-2 of the Arctic Fishery Management Plan (FMP) adopted by the United States North Pacific Fishery Management Council on 5 February 2009, effective 3 December 2009 (50 CFR Part 679; Federal Register, Vol. 74, No. 211, of 3 November 2009, p. 56734 (all available at <www.fakr.noaa.gov/npfmc>, accessed 26 September 2011). 


\section{Annex I: Current Status of Participation in the Spitsbergen Treaty}

Table 2. Status of Participation in the Spitsbergen Treaty ${ }^{216}$

\begin{tabular}{|c|c|c|c|c|}
\hline Nr. & State & Ratification & Accession & Entry into force \\
\hline 1 & Afghanistan & & 23 November 1925 & 23 November 1925 \\
\hline 2 & Albania & & 29 April 1930 & 29 April 1930 \\
\hline 3 & Argentina & & 6 May 1927 & 6 May 1927 \\
\hline 4 & Australia & 29 December 1923 & & 14 August 1925 \\
\hline 5 & Austria $^{\mathrm{d}}$ & & 12 March 1930 & 12 March 1930 \\
\hline 6 & Belgium $^{d}$ & & 27 May 1925 & 14 August 1925 \\
\hline 7 & Bulgaria $^{\mathrm{d}}$ & & 20 October 1925 & 20 October 1925 \\
\hline 8 & Canada & 29 December 1923 & & 14 August 1925 \\
\hline 9 & Chile & & 17 December 1928 & 17 December 1928 \\
\hline 10 & China & & 1 July 1925 & 1 July 1925 \\
\hline 11 & Czech Republic ${ }^{\mathrm{d}}$ & & 21 June 2006 & 1 January 1993 \\
\hline 12 & Denmark $^{\text {ad }}$ & 24 January 1924 & & 14 August 1925 \\
\hline 13 & Dominican Republic & & 3 February 1927 & 3 February 1927 \\
\hline 14 & Egypt & & 13 September 1925 & 13 September 1925 \\
\hline 15 & Estonia $^{\mathrm{d}}$ & & 7 April 1930 & 7 April 1930 \\
\hline 16 & Finland $^{\mathrm{d}}$ & & 12 August 1925 & 14 August 1925 \\
\hline 17 & France $^{\mathrm{d}}$ & 6 September 1924 & & 14 August 1925 \\
\hline 18 & Germany $^{\mathrm{d}}$ & & 16 November 1925 & 16 November 1925 \\
\hline 19 & Greece $^{\mathrm{d}}$ & & 21 October 1925 & 21 October 1925 \\
\hline 20 & Hungary ${ }^{d}$ & & 29 October 1927 & 29 October 1927 \\
\hline 21 & Iceland ${ }^{d}$ & & 31 May 1994 & 31 May 1994 \\
\hline 22 & India & 29 December 1923 & & 14 August 1925 \\
\hline 23 & Ireland $^{\mathrm{d}}$ & 29 December 1923 & & 14 August 1925 \\
\hline 24 & Italy ${ }^{d}$ & 6 August 1924 & & 14 August 1925 \\
\hline 25 & Japan & 2 April 1925 & & 14 August 1925 \\
\hline 26 & Monaco & & 22 June 1925 & 14 August 1925 \\
\hline 27 & Netherland $s^{\mathrm{bd}}$ & 3 September 1920 & & 14 August 1925 \\
\hline 28 & New Zealand & 29 December 1923 & & 14 August 1925 \\
\hline 29 & Norway & 8 October 1924 & & 14 August 1925 \\
\hline 30 & Poland ${ }^{\mathrm{d}}$ & & 2 September 1931 & 2 September 1931 \\
\hline 31 & Portugal $^{\mathrm{d}}$ & & 24 October 1927 & 24 October 1927 \\
\hline 32 & Romania $^{\mathrm{d}}$ & & 10 July 1925 & 14 August 1925 \\
\hline 33 & Russian Federation & & 7 May 1935 & 7 May 1935 \\
\hline 34 & South Africa & 29 December 1923 & & 14 August 1925 \\
\hline 35 & Spain $^{\mathrm{d}}$ & & 12 November 1925 & 12 November 1925 \\
\hline 36 & Sweden ${ }^{\mathrm{d}}$ & 15 September 1924 & & 14 August 1925 \\
\hline 37 & Switzerland & & 30 June 1925 & 14 August 1925 \\
\hline 38 & United Kingdom ${ }^{\mathrm{d}}$ & 29 December 1923 & & 14 August 1925 \\
\hline 39 & United States of America & 2 April 1924 & & 14 August 1925 \\
\hline 40 & Venezuela & & 8 February 1928 & 8 February 1928 \\
\hline
\end{tabular}

${ }^{216}$ As reflected in the treaty database of the Netherlands Ministry of Foreign Affairs, <www .minbuza.nl/verdragen/004293>, accessed on 13 September 2011. Yugoslavia acceded to the Spitsbergen Treaty on 6 July 1925, became a party on 14 August 1925, but was dissolved on 25 June 1991. A Norwegian website (<lovdata.no/traktater/index.html>, accessed on 13 September 2011) also lists Saudi Arabia as a contracting party; incorrectly so it seems. 
a Also extends to the Faroe Islands and Greenland.

b As regards the Netherlands in Europe. Also extends to Aruba (from 1 January 1986) and Bonaire, Sint Eustatius, Saba, Curaçao and Sint Maarten (from 10 October 2010).

c State succession. Czechoslovakia acceded to the Spitsbergen Treaty on 9 July 1930. The Czech Republic deposited its instrument of succession on 21 June 2006, presumably specifying that adherence by means of succession was to be applied as from 1 January 1993.

${ }^{d}$ EU Member State. 